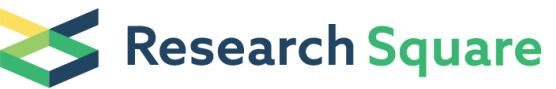 \\ Preprints are preliminary reports that have not undergone peer review. \\ They should not be considered conclusive, used to inform clinical practice, \\ or referenced by the media as validated information.
}

\section{Targeting fibroblast activation protein (FAP): Next generation PET radiotracers using squaramide coupled bifunctional DOTA and DATA5m chelators}

\section{Euy Sung Moon}

Johannes Gutenberg-Universitat Mainz Fachbereich Chemie Pharmazie und Geowissenschaften https://orcid.org/0000-0003-0447-1355

\section{Filipe Elvas}

Universiteit Antwerpen Faculteit geneeskunde en gezondheidswetenschappen

\section{Gwendolyn Vliegen}

Universiteit Antwerpen Faculteit Farmaceutische Biomedische en Diergeneeskundige Wetenschappen

\section{Stef De Lombaerde}

Universiteit Antwerpen Faculteit geneeskunde en gezondheidswetenschappen

\section{Christel Vangestel}

Universiteit Antwerpen Faculteit geneeskunde en gezondheidswetenschappen

\section{Sven De Bruycker}

Universiteit Antwerpen Faculteit geneeskunde en gezondheidswetenschappen

\section{An Bracke}

Universiteit Antwerpen Faculteit Farmaceutische Biomedische en Diergeneeskundige Wetenschappen

\section{Elisabeth Eppard}

PositronPharma

\section{Lukas Greifenstein}

Johannes Gutenberg-Universitat Mainz Fachbereich Chemie Pharmazie und Geowissenschaften

\section{Benedikt Klasen}

Johannes Gutenberg-Universitat Mainz Fachbereich Chemie Pharmazie und Geowissenschaften

\section{Vasko Kramer}

PositronPharma

\section{Steven Staelens}

Universiteit Antwerpen Faculteit geneeskunde en gezondheidswetenschappen

\section{Ingrid De Meester}

Universiteit Antwerpen Faculteit Farmaceutische Biomedische en Diergeneeskundige Wetenschappen

\section{Pieter Van der Veken}

Universiteit Antwerpen Faculteit Farmaceutische Biomedische en Diergeneeskundige Wetenschappen

Frank Roesch ( $\nabla$ frank.roesch@uni-mainz.de ) 


\section{Original research}

Keywords: DOTA, DATA5m, 68Ga, FAP, PREP, squaric acid, squaramide, HT-29

Posted Date: April 29th, 2020

DOI: https://doi.org/10.21203/rs.3.rs-24915/v1

License: (c) (i) This work is licensed under a Creative Commons Attribution 4.0 International License. Read Full License

Version of Record: A version of this preprint was published at EJNMMI Radiopharmacy and Chemistry on July 29th, 2020. See the published version at https://doi.org/10.1186/s41181-020-00102-z. 


\section{Abstract \\ Background}

Fibroblast activation protein (FAP) is a proline selective serine protease that is overexpressed in tumor stroma and in lesions of many other diseases that are characterized by tissue remodeling. In 2014, a most potent FAP-inhibitor (referred to as UAMC1110) with low nanomolar FAP-affinity and high selectivity toward related enzymes such as prolyl oligopeptidase (PREP) and the dipeptidyl-peptidases (DPPs): DPP4, DPP8/9 and DPP2 were developed. This inhibitor has been adopted recently by other groups to create radiopharmaceuticals by coupling bifunctional chelator-linker systems. Here, we report squaric acid containing bifunctional DATA ${ }^{5 \mathrm{~m}}$ and DOTA chelators relied on UAMC1110.

\section{Results}

The radiopharmaceuticals DOTA.SA.FAPi and DATA ${ }^{5 \mathrm{~m}}$.SA.FAPi were synthesized, labeled with gallium-68 and further characterized for in vitro stability, inhibitory efficiency, in vivo targeting properties and ex vivo biodistribution. $\left[{ }^{68} \mathrm{Ga}\right] \mathrm{Ga}-D O T A . S A . F A P i$ and $\left[{ }^{68} \mathrm{Ga}\right] \mathrm{Ga}-D A T A^{5 \mathrm{~m}}$.SA.FAPi showed high complexation after already 10 minutes and high stability over a period of $2 \mathrm{~h}$. Affinity to FAP of DOTA.SA.FAPi and its ${ }^{\text {nat }} \mathrm{Ga}$ and nat Lu-labeled derivatives were in low nanomolar range. Comparable results were obtained for DATA $^{5 \mathrm{~m}}$.SA.FAPi and its ${ }^{\text {nat }} \mathrm{Ga}$ analogue. Additionally, all five compounds showed low affinity for the related protease PREP (high $\mu \mathrm{M}$ range). First proof-of-principle in vivo PET-imaging animal studies of the $\left[{ }^{68} \mathrm{Ga}\right]$ Ga-DOTA.SA.FAPi precursor in a HT-29 human colorectal cancer xenograft mouse model indicated promising results with high accumulation in tumor and low background signal. Ex vivo biodistribution showed high tumor uptake at 60 min post injection with overall low uptake in healthy tissues.

\section{Conclusion}

In this work, novel PET radiotracers targeting fibroblast activation protein (FAP) were synthesized and biochemically investigated. Critical substructures of the novel compounds are a squaramide linker unit derived from the basic motif of squaric acid, DOTA and DATA ${ }^{5 m}$ bifunctional chelators and a FAPtargeting moiety. In conclusion, these new FAP-ligands appear promising, both for further research and development as well as for first human application.

\section{Background}

The proline-selective serine protease fibroblast activation protein (FAP) is a type II transmembrane glycoprotein with 760 amino acids. It is related to the dipeptidyl peptidases (DPPs) DPP2, DPP4, DPP8 and DPP9 and furthermore related to the endopeptidase prolyl oligopeptidase (PREP).[1, 2] FAP combines DPP and endopeptidase activities.[3-6] With respect to FAP's endopeptidase activity, a remarkable 
preference is present for cleavage after Gly-Pro motifs in peptides.[7] FAP is not detectable in most healthy adult tissues and therefore considered non-essential under normal circumstances. However, it is clearly expressed in pathophysiological lesions, characterized by tissue remodeling. Such lesions can be found in, e.g., cancer, atherosclerosis, arthritis and several fibrosis types.[8, 9] Over the past two decades, significant attention has gone to FAP in solid tumors, where it is mainly expressed on so-called cancer associated fibroblasts (CAFs).[10,11] These are activated fibroblasts with a myofibroblast phenotype.[12] There is growing evidence that CAFs have a regulatory role in tumor biology and extracellular matrix

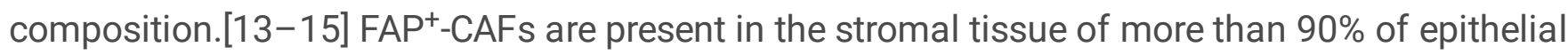
carcinomas, including pancreatic, colon, ovarian, lung and breast cancer.[16, 17] Generally speaking, the tumor stroma contains a large part of the tumor mass ( $>90 \%$ of tumor mass in carcinomas) and is therefore an attractive target for diagnostic and therapeutic radiopharmaceuticals. Conferring stroma affinity to these radiopharmaceuticals by incorporating a FAP-inhibitor moiety is, based on the presence of $\mathrm{FAP}^{+}-\mathrm{CAFs}$, a potentially rewarding strategy.

Several highly potent FAP-inhibitors have been reported earlier.[18, 19] First-generation compounds with a boronic acid warhead, however, are plagued by a lack of selectivity with respect to the related enzymes and are also characterized by lower chemical stability. More recently, compounds with a more stable carbonitrile warhead have been reported.[20,21] One of the most promising molecules to date is UAMC1110 (Fig. 1). This molecule combines low nanomolar FAP affinity and high selectivity with respect to both the DPPs and PREP. The high FAP-selectivity of UAMC1110 is particularly attractive for tumortargeting, when taking into account the near-ubiquitous expression of the DPPs and PREP in humans. In addition, this molecule possesses a satisfactory pharmacokinetic profile.

UAMC1110 is currently still under evaluation as a potential therapeutic in diseases characterized by FAP expression. At the same time, the molecule is being used as a FAP-targeting moiety in so-called activitybased probes that can be used to visualize and quantify FAP activity in tissues and organisms.[22] Highly relevant examples have also been published that rely on radionuclide-based reporter systems, such as XY-FAP-02 developed by Yang et al.[23] They used a DOTAGA chelator combined with an alkyl chain as linker system bound to the FAP-inhibitor.

Further developments by Lindner and Loktev et al. using radiolabeled [UAMC1110-chelator]-conjugates have shown promising results in preclinical and first clinical patient studies. Applications of these molecules cover both diagnosis and therapy.[24-29] First, a DOTA-FAPI conjugate using piperazine as linker (referred to as FAPI-02 in the original reference) was synthesized and characterized with respect to binding, internalization, and efflux in cells expressing human and murine FAP as well as CD26. PETimaging studies of HT-1080 tumor xenografts showed low $\left[{ }^{68} \mathrm{Ga}\right] \mathrm{Ga}$-FAPI-02 accumulation in normal tissues and a rapid clearance from the blood via kidneys and bladder. In addition, a high tumor uptake resulting in high tumor-to-normal organ-ratio was determined. By structural variation, especially in the linker region, more analogous ${ }^{68} \mathrm{Ga}$-labeled compounds were obtained. Several of these had improved imaging parameters, with FAPI-04, FAPI-21 and FAPI-46 being relevant examples. $[25,26]$ These 
compounds also had low nanomolar FAP-affinity $\left(\mathrm{IC}_{50}=6.5 \mathrm{nM}\right.$ for FAPI-04, IC $\mathrm{C}_{50}=6.7 \mathrm{nM}$ for FAPI-21 and $\mathrm{IC}_{50}=13.5 \mathrm{nM}$ for FAPI-46), higher tumor uptakes in vivo and longer tumor retention times. First PET/CT imaging studies of patients diagnosed with different tumor entities were performed with the ${ }^{68} \mathrm{Ga}$ compounds indicating high tumor uptake and low background in healthy organs. As an example of a first therapeutic application, patients diagnosed with metastatic breast cancer were treated with $\left[{ }^{90} \mathrm{Y}\right] \mathrm{Y}$-FAPI04. The ${ }^{68} \mathrm{Ga} /{ }^{90} \mathrm{Y}$-DOTA-derivatives represent promising tracers for both diagnostic imaging and, possibly, targeted therapy of malignant tumors with high accumulated activated fibroblasts.

In this work, novel FAP-targeting radiotracers were evaluated using bifunctional DOTA and DATA $5 \mathrm{~m}$ chelators coupled by squaramide as linker moiety. The basic motif squaric acid (SA) is a cyclic aromatic diacid.[30, 31] One advantage of SA is the simple chemistry regarding coupling to chelator and target vector including that no protecting groups are necessary due its selectivity for primary amines. Especially reactions with biomolecules are attractive and no side reactions are observed. The coupling with SAdiester is a highly selective, $\mathrm{pH}$ controlled asymmetric amidation under mild conditions.[32] In a neutral $\mathrm{pH}$, only one ester of the SA-diester reacts with an amine and by increasing the $\mathrm{pH}$ to basic conditions, amidation of the second ester takes place. The use of SA as a linker unit between a chelator-biomolecule conjugate as a radiopharmaceutical was demonstrated using DFO and conjugation on a peptide to complex iron and using DFO-squaric acid coupled to antibodies for complexing ${ }^{89} \mathrm{Zr}$.[33, 34] Recently, our group published the usage of SA as a linker forming a radiotracer with the bifunctional hybrid chelator AAZTA ${ }^{5}$ coupled to a PSMA inhibitor unit (KuE) and evaluated those AAZTA ${ }^{5}$.SA.PSMA conjugate with various radionuclides such as ${ }^{44} \mathrm{Sc},{ }^{64} \mathrm{Cu},{ }^{68} \mathrm{Ga}$ and ${ }^{177} \mathrm{Lu}$.[35] Additionally, we indicate a second feature of SA beyond coupling chemistry. In several cases we could observe a positive impact on pharmacology of the final products. $\left[{ }^{68} \mathrm{Ga}\right] \mathrm{Ga}-N O D A G A . S A . P S M A,\left[{ }^{68} \mathrm{Ga}\right] \mathrm{Ga}-T R A M . S A . P S M A$ and $\left[{ }^{68} \mathrm{Ga}\right] \mathrm{Ga}-$ DOTAGA.SA.PSMA showed high tumor uptake and overall high tumor-to-organ ratio. $\left[{ }^{68} \mathrm{Ga}\right] \mathrm{Ga}$ DOTAGA.SA.PSMA provided in vivo in LNCaP-tumor bearing mice comparable results to $\left[{ }^{68} \mathrm{Ga}\right] \mathrm{Ga}-\mathrm{PSMA}-$ 617 and $\left[{ }^{68} \mathrm{Ga}\right] \mathrm{Ga}-\mathrm{PSMA}-11$ with significant tumor accumulation.[36]

Here, the preparative synthesis of DOTA.SA.FAPi and DATA ${ }^{5 \mathrm{~m}}$.SA.FAPi and the metal-analogs $\left[{ }^{\text {nat }} \mathrm{Ga}\right] \mathrm{Ga}-$ DOTA.SA.FAPi, $\left[{ }^{\text {nat }} \mathrm{Ga}\right.$ ]Ga-DATA ${ }^{5 \mathrm{~m}}$.SA.FAPi and [ ${ }^{\text {nat }} \mathrm{Lu}$ ]Lu-DOTA.SA.FAPi are described. The macrocyclic chelator DOTA was used to allow labeling with both ${ }^{68} \mathrm{Ga}$ and ${ }^{177} \mathrm{Lu}$. However, one disadvantage of these chelator types are the requirement of high temperatures for complexation.[37] DATA ${ }^{5 m}$, a bifunctional version of the hybrid chelator DATA, was used to allow instant ${ }^{68} \mathrm{Ga}$-labeling at room temperature.[38-40] Radiochemical evaluation with regard to labeling and in vitro stability studies were performed with ${ }^{68} \mathrm{Ga}$ for DOTA.SA.FAPi and DATA ${ }^{5 \mathrm{~m}}$.SA.FAPi. For all the five cold compounds, inhibition assays were carried out and $\mathrm{IC}_{50}$ values obtained for FAP and PREP. In a first proof-of-principle PET-study, $\left[{ }^{68} \mathrm{Ga}\right] \mathrm{Ga}$ DOTA.SA.FAPi was tested in vivo using a FAP-expressing HT-29 human colorectal adenocarcinoma xenograft model.

\section{Results}




\section{Synthesis of DOTA.SA.FAPi}

The commercially available D03AtBu- $N$-(2-aminoethyl)ethanamide 1 was treated with trifluoroacetic acid (TFA) to deprotect the tert-butyl groups. Since the coupling of squaric acid diethyl ester (SADE) with primary amines is selective, no protective groups were necessary for the next synthesis steps. The deprotected D03A- $N$-(2-aminoethyl)ethanamide was coupled to SADE in phosphate buffer $(\mathrm{pH} 7)$ at ambient temperature and purified via HPLC to receive DOTA.SA 2. The free coupling side of 2 was afterwards coupled to (S)-6-(4-aminobutoxy)- $N$-(2-(2-cyano-4,4-difluoropyrrolidin-1-yl)-2-oxoethyl)quinoline-4-carboxamide 3 (termed $\mathrm{NH}_{2}-\mathrm{FAPi}$ ) in phosphate buffer $(\mathrm{pH} 9)$ at room temperature. After successful HPLC purification, DOTA.SA.FAPi 4 was obtained (Fig. 3).

\section{Synthesis of DATA ${ }^{5 m}$.SA.FAPi}

DATA ${ }^{5 m_{-}} 3^{t} B u 5$ was synthesized as described by Seemann et al. (Figure 4). [38] DATA ${ }^{5 m_{-}} 3^{t}$ Bu provides a bifunctional carbonyl group for further coupling with spacer molecules or target vectors. Terminal primary amines are required for binding to SA-diethylester. Therefore $N$-boc-ethylenediamine was attached to the carboxylic acid group of DATA ${ }^{5 m}$ via common coupling reagents HATU in DIPEA and MeCN receiving 6. Amidation of SA-monoester $\mathbf{7}$ with the terminal amine of $\mathrm{NH}_{2}$-FAPi was executed analogously to DOTA.SA.FAPi to receive DATA ${ }^{5 m}$.SA.FAPi 8.

\section{Synthesis of cold complexes and enzyme inhibition assays}

Cold complexes of [ $\left.{ }^{\text {nat }} \mathrm{Ga}\right] \mathrm{Ga}$-DOTA.SA.FAPi, $\left[{ }^{\text {nat }} \mathrm{Ga}\right.$ ]Ga-DATA ${ }^{5 \mathrm{~m}}$.SA.FAPi and [ ${ }^{\text {nat }} \mathrm{Lu}$ ]Lu-DOTA.SA.FAPi were synthesized. The corresponding precursors were reacted with a $10 \mathrm{mM}$ solution of the metal chlorides or nitrates in $0.2 \mathrm{M} \mathrm{NaAc}$ buffer $\mathrm{pH}$ 4.5. The solutions of nat $\mathrm{Ga}$ and ${ }^{\text {nat }} \mathrm{Lu}$ complexed DOTA.SA.FAPi were shaken for $3 \mathrm{~h}$ at $95^{\circ} \mathrm{C}$ and the solution of ${ }^{\text {nat }} \mathrm{Ga}$-metalled DATA ${ }^{5 \mathrm{~m}}$.SA.FAPi was shaken for $2 \mathrm{~h}$ at RT. Complexations were monitored by ESI LC-MS and the metal complexes were purified via HPLC.

In the inhibition assays, DOTA.SA.FAPi and DATA ${ }^{5 m}$.SA.FAPi, along with their non-radioactive, metal complexed analogues were characterized for inhibitory potency towards FAP and PREP. Earlier work had shown that the lack of a basic amine function in UAMC1110-based molecules, precludes DPP-affinity in this series.[21,22] Nonetheless, the FAP/PREP selectivity was shown to be a particularly important parameter to check. Obtained results are summarized in Table 1. Parent compound UAMC1110 was used as a reference in this assay. All the evaluated molecules displayed highly satisfactory, low nanomolar FAP potencies, in the same range as the parent inhibitor UAMC1110. This implies that introduction of a linker, a chelator and a metal ion at the selected position of the quinoline ring are tolerated by FAP and have no negative influence on target affinity. Likewise, equally satisfactory compound selectivities with respect to PREP were measured, again comparable with UAMC1110. 
Table $1 \mathrm{IC}_{50}$-values of DOTA.SA.FAPi, the ${ }^{\text {nat }} \mathrm{Ga}$ and ${ }^{\text {nat }} \mathrm{Lu}$-Complexes and DATA ${ }^{5 \mathrm{~m}}$.SA.FAPi and

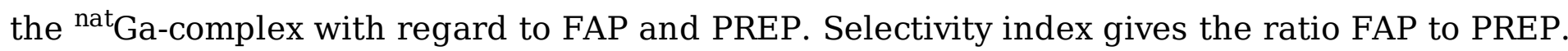

\begin{tabular}{|c|c|c|c|}
\hline & $\begin{array}{c}\mathrm{IC}_{50} \text { FAP } \\
(\mathrm{nM})\end{array}$ & $\begin{array}{c}\mathrm{IC}_{50} \text { PREP } \\
(\mu \mathrm{M})\end{array}$ & $\begin{array}{l}\text { Selectivity index }\left(\mathrm{IC}_{50}\right. \\
(\mathrm{FAP} / \mathrm{PREP}))\end{array}$ \\
\hline $\begin{array}{l}\text { DOTA.SA.FAPi - } \\
\text { uncomplexed }\end{array}$ & $0.9 \pm 0.1$ & $5.4 \pm 0.3$ & 6000 \\
\hline DOTA.SA.FAPi - ${ }^{\text {nat }} \mathrm{Ga}$ & $1.4 \pm 0.2$ & $8.7 \pm 0.9$ & 6214 \\
\hline DOTA.SA.FAPi $-{ }^{\text {nat }} \mathrm{Lu}$ & $0.8 \pm 0.2$ & $2.5 \pm 0.4$ & 3125 \\
\hline $\begin{array}{c}\text { DATA }^{5 \mathrm{~m}} \cdot \mathrm{SA} . \mathrm{FAPi}- \\
\text { uncomplexed }\end{array}$ & $0.8 \pm 0.2$ & $1.7 \pm 0.1$ & 2113 \\
\hline $\mathrm{DATA}^{5 \mathrm{~m}} \cdot \mathrm{SA} . \mathrm{FAPi}-{ }^{\text {nat }} \mathrm{Ga}$ & $0.7 \pm 0.1$ & $4.7 \pm 0.3$ & 6714 \\
\hline FAP-inhibitor UAMC1110 & $\begin{array}{l}0.43 \pm \\
0.07^{\mathrm{a}}\end{array}$ & $1.8 \pm 0.2^{\mathrm{b}}$ & 4186 \\
\hline
\end{tabular}

${ }^{a}$ Determined under the conditions of this study. ${ }^{\mathrm{b}}$ data from Jansen et al.[21]

\section{Radiochemical evaluations with gallium-68}

Radiolabeling of DOTA.SA.FAPi with ${ }^{68} \mathrm{Ga}$ was performed with varying amounts of the precursor (10$40 \mu \mathrm{g}$ ) and at $95^{\circ} \mathrm{C}$ (Figure 5). Labeling was performed in $1 \mathrm{M} \mathrm{AmAc}$ buffer (pH 5.5) at $95^{\circ} \mathrm{C}$ in triplicate $\mathrm{n}=3$ with around $200 \mathrm{MBq}$ of ${ }^{68} \mathrm{Ga}$. For precursor amounts of more than $15 \mu \mathrm{g}(16 \mathrm{nmol})$, a quantitative radiochemical yield of $>97 \%$ could be achieved in less than 5 minutes. At $10 \mu \mathrm{g}(11 \mathrm{nmol})$ a decreased RCY of $44 \%$ after 15 minutes could be observed. For further in vivo studies, $20 \mu \mathrm{g}$ was used as standard and C18 purification of $\left[{ }^{68} \mathrm{Ga}\right] \mathrm{Ga}$-DOTA.SA.FAPi was executed which results in a radiochemical purity of $>98 \%$. HPLC retention time of free gallium-68: $t_{R}\left({ }^{68} \mathrm{Ga}\right)$ was $4 \mathrm{~min}$ and the retention time of the complex $t_{R}\left(\left[{ }^{68} \mathrm{Ga}\right] \mathrm{Ga}-\mathrm{DOTA}\right.$.SA.FAPi $)$ was $9 \mathrm{~min}$. The $R_{\mathrm{f}}$ values of the radio-TLC were $R_{f}\left({ }^{68} \mathrm{Ga}\right)=0.9$ and $R_{f}$ $\left(\left[{ }^{68} \mathrm{Ga}\right] \mathrm{Ga}-\mathrm{DOTA}\right.$.SA.FAPi $)=0.1$ using citrate buffer $\mathrm{pH} 4$ as mobile phase.

Carrying out labeling at different temperatures $\left(70,80\right.$ and $\left.95^{\circ} \mathrm{C}\right)$ with a defined tracer amount of $30 \mu \mathrm{g}$ $(31 \mathrm{nmol})$ resulted in quantitative RCYs $>97 \%$ at temperatures of $80^{\circ} \mathrm{C}$ and $95^{\circ} \mathrm{C}$ after 15 minutes. At 70 ${ }^{\circ} \mathrm{C}$, complexation of ${ }^{68} \mathrm{Ga}$ via DOTA.SA.FAPi showed decreased radiolabeling efficiency, nevertheless resulting in >83 \% after $15 \mathrm{~min}$. (SI, Figure S3). 
Stability studies were performed in $\mathrm{EtOH}, \mathrm{HS}$ and saline $0.9 \%$ over a period of $2 \mathrm{~h}$ at $37^{\circ} \mathrm{C}$. In all three

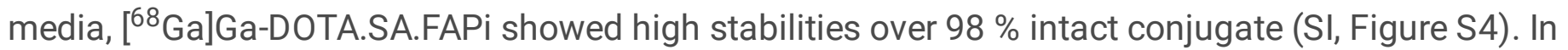
addition, stability against transmetallation and transchelation were carried out (SI, Figure S5, S6). Against DTPA and EDTA the stability values were $>98 \%$ and against $\mathrm{Cu}, \mathrm{Mg}$ and $\mathrm{Ca}$ the stabilities were $>95 \%$ after $2 \mathrm{~h}$. Stabilities against Fe showed >95\% after 90 minutes and a slightly lower value however still over $92 \%$ after $2 \mathrm{~h}$.

For radiolabeling of DATA ${ }^{5 m}$.SA.FAPi, various precursor amounts (1-20 $\left.\mu \mathrm{g}\right)$ in $1 \mathrm{M} \mathrm{AmAc} \mathrm{buffer} \mathrm{(pH} \mathrm{5.5)}$ were labeled with ${ }^{68} \mathrm{Ga}$. The reaction mixture was shaken for $10 \mathrm{~min}$ at room temperature to afford $\left[{ }^{68} \mathrm{Ga}\right] \mathrm{Ga}-\mathrm{DATA}{ }^{5 \mathrm{~m}} \cdot$ SA.FAPi.

First kinetic studies were performed with $200-230 \mathrm{MBq}$ of ${ }^{68} \mathrm{Ga}$ in $1 \mathrm{M} \mathrm{AmAc}$ buffer (pH 5.5) at RT ( $\left.\mathrm{n}=1\right)$. Quantitative RCYs $>98 \%$ could be achieved for precursor amounts of $15 \mu \mathrm{g}(16 \mathrm{nmol})$ and $20 \mu \mathrm{g}(21$ $\mathrm{nmol})$ in less than 1 minute. Analogous to [ $\left.{ }^{68} \mathrm{Ga}\right] \mathrm{Ga}-D O T A . S A . F A P i, ~\left[{ }^{68} \mathrm{Ga}\right] \mathrm{Ga}-D A T A{ }^{5 m}$.SA.FAPi also showed significantly lower RCY below $15 \mu \mathrm{g}$. At $10 \mu \mathrm{g}(10 \mathrm{nmol})$ only a RCY of $38 \%$ and for $5 \mu \mathrm{g}$ a RCY of just $12 \%$ after 10 minutes could be observed. HPLC retention times of free gallium-68 $t_{R}\left({ }^{68} \mathrm{Ga}\right)$ and of the complex $t_{R}\left(\left[{ }^{68} \mathrm{Ga}\right] \mathrm{Ga}-\mathrm{DATA}{ }^{5 \mathrm{~m}}\right.$.SA.FAPi $)$ were $4 \mathrm{~min}$ and $8.5 \mathrm{~min}$, respectively. The $R_{\mathrm{f}}$ values of the radio-TLC were $R_{f}\left({ }^{68} \mathrm{Ga}\right)=0.9$ and $R_{f}\left(\left[{ }^{68} \mathrm{Ga}\right] \mathrm{Ga}-\mathrm{DATA}{ }^{5 \mathrm{~m}}\right.$.SA.FAPi $)=0.1$ using citrate buffer pH 4 as mobile phase. In addition, it was investigated whether a lower amount of activity has an influence on better complexation. Therefore $10 \mu \mathrm{g}$ of the precursor were labeled with around $60 \mathrm{MBq}$ of ${ }^{68} \mathrm{Ga}$ in triplicate. The lower activity improved complexation of $\left[{ }^{68} \mathrm{Ga}\right] \mathrm{Ga}-\mathrm{DATA}{ }^{5 \mathrm{~m}}$.SA.FAPi. Using $10 \mathrm{nmol}$ of precursor, a quantitative yield could be achieved instead of $38 \%$ as before. Stability of $\left[{ }^{68} \mathrm{Ga}\right] \mathrm{Ga}-$ DATA $^{5 \mathrm{~m}}$.SA.FAPi was determined in PBS, HS and saline $0.9 \%$ over a period of $120 \mathrm{~min}$. In all three media, the stability of $\left[{ }^{68} \mathrm{Ga}\right] \mathrm{Ga}-\mathrm{DATA}{ }^{5 \mathrm{~m}}$.SA.FAPi remained $>95 \%$ (SI, Figure S7).

\section{PET/CT-imaging and ex vivo biodistribution data of $\left[{ }^{68} \mathrm{Ga}\right] \mathrm{Ga}-D O T A . S A . F A P i$}

For investigation of the tumor uptake by $\left[{ }^{68} \mathrm{Ga}\right] \mathrm{Ga}-D O T A . S A . F A P i ~ H T-29$ tumor-bearing mice $(\mathrm{n}=3)$ were sacrificed after PET/CT scans and an ex vivo biodistribution study was executed. In the PET images, the tumor accumulation is clearly visible and the ratio to nonspecific organs and tissues is very high. Figure 7 shows the maximum intensity projection (MIP) images of three mice. Ex vivo biodistribution is shown in Figure $8 \mathrm{a}$. The highest accumulation was observed in the tumor with an uptake of $5.2 \pm 0.2 \% \mathrm{ID} / \mathrm{g} 1 \mathrm{~h}$ post injection (p.i.). In general, the tumor-to-organ ratios are high after $1 \mathrm{~h}$ p.i. which is shown by, e.g., tumor-to-blood $(9.2 \pm 1.1)$, tumor-to-large intestine $(24.9 \pm 1.7)$ and tumor-to-muscle $(11.5 \pm 2.2)$ ratios (Figure 8b). Uptake in other organs are also low such as in heart, lungs, liver, spleen, pancreas, stomach, fat and skin. In addition to the tumor accumulation, a slightly higher accumulation at the bones and 
small intestine was found, which cannot yet be fully explained. One suggestion could be that FAP is also expressed in these tissues. However, it is important that the main accumulation is located in the tumor.

\section{Discussion}

Two novel bifunctional chelator-linker conjugates based on the FAP inhibitor UAMC1110 were developed. As bifunctional chelators, macrocyclic DOTA as well as the hybrid chelator DATA ${ }^{5 m}$ were used. Squaric acid is the main component of the linker system forming a squaramide unit and accordingly substitutes the heterocyclic nitrogen moieties in the structures reported by the Heidelberg group.[24-26] The asymmetrically substituted squaramide unit in the target compounds was efficiently installed with SADE, relying on the latter's elegant $\mathrm{pH}$-dependent chemistry and selectivity for primary amines. Due to this selectivity, no protecting groups are required. In addition, the $\mathrm{pH}$ dependent reactivity of SADE is explained by changes of the aromatic stabilization energy in the ring system over the course of the sequential amidation steps.[32] After the first amidation, which is carried out at neutral $\mathrm{pH}$, the obtained uncharged monoamide is characterized by a higher aromatic stabilization than the starting material, squaric acid diester. This stabilization prevents addition of a second amine molecule. By increasing the $\mathrm{pH}$, the monoamide is deprotonated, loses aromatic stabilization, and this allows for addition of a second amine molecule to provide the diamide.[30, 41] Correspondingly, $\mathrm{C}_{2}$-symmetric diamide derivatives of squaric acid can be obtained, if the reaction is performed at higher $\mathrm{pH}$ : in that case, two equivalents of amine will directly substitute the ethoxy groups in SADE.

Both DOTA.SA.FAPi and DATA ${ }^{5 \mathrm{~m}}$.SA.FAPi could be well used for radiolabeling with ${ }^{68} \mathrm{Ga}$. DATA has already demonstrated good complexation with ${ }^{68} \mathrm{Ga}$ and has the advantage of labeling even under mild conditions such as room temperature. Quantitative gallium-68 labeling results were observed for both FAPi-conjugates with ${ }^{68} \mathrm{Ga}$. The DOTA complex showed quantitative radiochemical yields at temperatures of $95^{\circ} \mathrm{C}$ with precursor amounts of $>15 \mathrm{nmol}$. For the DATA ${ }^{5 \mathrm{~m}}$ conjugate quantitative yields could be achieved at room temperature for amounts $>15 \mathrm{nmol}$. In addition, it could be seen that with a lower activity of ${ }^{68} \mathrm{Ga}$, less precursor amount $(\geq 10 \mathrm{nmol})$ is required to achieve quantitative complexation, whereas with higher gallium activity $(>200 \mathrm{MBq})$ more substance $>15 \mathrm{nmol}$ is needed for quantitative yields.

The stability for both derivatives against different media was high with $>95 \%$ intact conjugates. $\left[{ }^{68} \mathrm{Ga}\right] \mathrm{Ga}-D O T A . S A . F A P i$ proved stable in $\mathrm{EtOH}, \mathrm{HS}$ and saline and was stable against transmetallation ( $\mathrm{Cu}, \mathrm{Mg}, \mathrm{Ca}$ and $\mathrm{Fe}$ ) and transchelation (DTPA and EDTA). Stability of $\left[{ }^{68} \mathrm{Ga}\right] \mathrm{Ga}-\mathrm{DATA}{ }^{5 \mathrm{~m}}$.SA.FAPi in HS, PBS and in saline is very high with $>95 \%$ intact conjugates over a period of $2 \mathrm{~h}$.

All five measured compounds, DOTA.SA.FAPi, $\left[{ }^{\text {nat } G a] G a-D O T A . S A . F A P i, ~}\left[{ }^{\text {nat }} \mathrm{Lu}\right] \mathrm{Lu}-D O T A . S A . F A P i\right.$, DATA $^{5 \mathrm{~m}}$.SA.FAPi and [ $\left.{ }^{\text {nat }} \mathrm{Ga}\right] \mathrm{Ga}-\mathrm{DATA}{ }^{5 \mathrm{~m}}$.SA.FAPi demonstrated very high affinity to FAP with low nanomolar $\mathrm{IC}_{50}$ values and high $\mathrm{IC}_{50}$ values with respect to PREP. Therefore, all measured FAP inhibitors 
have a potency in the same order of magnitude as the original FAP inhibitor. In addition, they all presented excellent selectivity for FAP with regard to PREP.

Preclinical in vivo animal studies were performed with HT-29 xenograft mice. The HT-29 cancer cell line is a human colorectal adenocarcinoma cell line with epithelial morphology.[42, 43] When inoculated into nude mice, they produce undifferentiated tumors with modest stroma. Significant FAP expression is present in this stroma, that typically trabeculates between nests of HT-29 cells. Notably, and similar to the situation in most tumor types, FAP staining is distinctly absent from the actual HT-29 cancer cells within the tumors.[43]

The highest accumulation in the tumor was found in both the PET images and biodistribution with an overall uptake of $5.2 \% \mathrm{ID} / \mathrm{g} 60$ min post injection. In addition, the tumor-to-organ ratios were quite high (tumor-to-blood ( $9.2 \pm 1.1)$, tumor-to-large intestine $(24.9 \pm 1.7)$ and tumor-to-muscle $(11.5 \pm 2.2)$ ), which is also reflected by the high contrast in the images. Besides the high tumor uptake, accumulation in the bladder could also be observed, suggesting renal clearance to be the predominant excretion.

\section{Conclusion}

In this work, two potential theranostic radiopharmaceuticals were successfully synthesized, based on the selective FAP-inhibitor UAMC1110. Key elements of these compounds are a squaramide motif

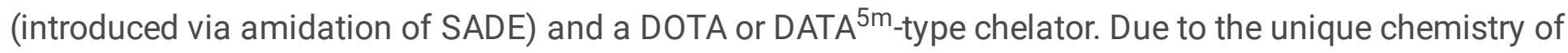
$S A D E$, it was possible to avoid complex synthesis routes and protective group strategies. In recent works from our group, SA has shown good results, both in chemistry and physiologically, as a linker unit coupled with PSMA inhibitors.[35, 36] DOTA.SA.FAPi and DATA ${ }^{5 \mathrm{~m}}$.SA.FAPi showed very good in vitro complexations of ${ }^{68} \mathrm{Ga}$ and a very high stability in different media of more than $95 \%$ intact conjugate. In general, the hybrid chelator DATA ${ }^{5 \mathrm{~m}}$ shows a quantitative complexation under mild conditions and is therefore very well suited to label temperature sensitive target molecules with radiometals. Additionally, DATA is well known for fast and stable complexation of ${ }^{68} \mathrm{Ga}$ and to show high stabilities over a long period of time. DOTA is interesting because of its ability to complex other radiometals preferring higher coordination numbers, e.g., the long-lived therapy radionuclide ${ }^{177} \mathrm{Lu}$ but also shorter-lived therapeutic radionuclides such as ${ }^{213} \mathrm{Bi},{ }^{210} \mathrm{~Pb}$ and ${ }^{90} \mathrm{Y}$. DOTA.SA.FAPi allows to use the same precursor for both diagnosis with ${ }^{68} \mathrm{Ga}$ and therapy with ${ }^{177} \mathrm{Lu}$ in nuclear medicine.

Both FAPi-precursors as well as their gallium and lutetium versions showed excellent affinity and selectivity to $\mathrm{FAP}$, in the low nanomolar range, with $\mathrm{IC}_{50}$-values between 0.7 and $1.4 \mathrm{nM}$. Conversely, PREP $\mathrm{IC}_{50}$-values were found to be in the $\mu \mathrm{M}$-range, implying excellent FAP/PREP selectivity indices.

In the HT-29 colon cancer xenograft model, first proof-of-concept animal studies with [ $\left.{ }^{68} \mathrm{Ga}\right] \mathrm{Ga}$ DOTA.SA.FAPi showed good tumoral accumulation with high uptake of $5.2 \pm 0.2 \% \mathrm{ID} / \mathrm{g}$ on average at 60 min p.i. and low background activity, i.e. an overall good tumor-to-organ ratio. 
The potential of the novel compound family to target FAP could be clearly demonstrated. In further preclinical characterizations we will also investigate the in vivo properties of $\left[{ }^{68} \mathrm{Ga}\right] \mathrm{Ga}-\mathrm{DATA}{ }^{5 \mathrm{~m}}$.SA.FAPi and publish these results at a later stage. We expect to apply these new radiotracers for various tumor types in nuclear medicine both in diagnosis and therapy.

\section{Materials And Methods}

\section{Reagents and instrumentations for synthesis}

All basic chemicals were acquired from Sigma-Aldrich (St. Louis, USA), Merck KGaA (Darmstadt, Germany), TCI Deutschland GmbH (Eschborn, Germany) and VWR International GmbH (Darmstadt, Germany). DOT3AtBu- $N$-(2-aminoethyl)ethanamide 1 was purchased from CheMatech (Dijon, France), (S)-6-(4-aminobutoxy)- $N$-(2-(2-cyano-4,4-difluoropyrrolidin-1-yl)-2-oxoethyl)-quinoline-4-carboxamide 3 was purchased from KE Biochem Co. (Shanghai, China). Thin-layer chromatography plates from Merck, Kieselgel 60 F254 coated aluminum plates, were used for the analysis. Detection was carried out by fluorescence extinction at $\lambda=254 \mathrm{~nm}$ and by staining with potassium permanganate. Silica gel 60 (core size $0.0630 .200 \mathrm{~mm}$ ) from Acros Organics (Schwerte, Germany) was used for purification by column chromatography. The LC/MS spectra were measured on an Agilent Technologies 1220 Infinity LC system coupled to an Agilent Technologies 6130B Single Quadrupole LC/MS system. The ${ }^{1} \mathrm{H}$ and ${ }^{13} \mathrm{C}$ NMR measurements were performed at $400 \mathrm{MHz}(400 \mathrm{MHz}$ FT NMR spectrometer AC 400, Bruker Analytik $\mathrm{GmbH}$ ). For analytical and semi-preparative HPLC a 7000 series Hitachi LaChrom with a Phenomenex (Aschaffenburg, Germany) Luna C18 $(250 \times 4.6 \mathrm{~mm}, 5 \mu)$ column, a Phenomenex Luna C18 (250 × $10 \mathrm{~mm}, 10 \mu)$ column and a Phenomenex Synergi C18 $(250 \times 10 \mathrm{~mm}, 4 \mu)$ column were used.

\section{Organic Synthesis}

\section{Synthesis of DOTA.SA.FAPi}

DOTA.SA ( 2 ) [2,2',2"-(10-(2-((2-((2-ethoxy-3,4-dioxocyclobut-1-en-1-yl)amino)ethyl)amino)-2oxoethyl)-1,4,7,10-tetraazacyclododecane-1,4,7-triyl)triacetic acid]

1 (48.0 mg; $78.1 \mu \mathrm{mol})$ was reacted with $1 \mathrm{~mL} 80 \%$ TFA in DCM for $6 \mathrm{~h}$ at room temperature for deprotection of tert-butyl protecting groups. After evaporating TFA/DCM, the residue was reacted with 3,4diethoxycyclobut-3-ene-1,2-dione (13.3 mg; $78.1 \mu \mathrm{mol}$ ) in $500 \mu \mathrm{L} 0.5 \mathrm{M} \mathrm{Na}_{2} \mathrm{HPO}_{4} / \mathrm{NaH}_{2} \mathrm{PO}_{4}$ phosphate buffer $\mathrm{pH} 7$ and shaken at room temperature overnight. The chelator-linker conjugate DOTA.SA 2 could be isolated via HPLC purification. After HPLC purification (Phenomenex® Luna ${ }^{\circledR} 10 \mu \mathrm{m} \mathrm{C18}$ (2) $100 \AA$, gradient $6-8 \% \mathrm{MeCN}(+0.1 \%$ TFA) / $9492 \%$ Water (+ $0.1 \%$ TFA) in 20 min with a $5 \mathrm{~mL} / \mathrm{min}$ flow) and lyophilization the product was obtained as white powder $(28.2 \mathrm{mg} ; 49.4 \mu \mathrm{mol} ; 63 \%)$. ${ }^{1} \mathrm{H}-\mathrm{NMR}\left(\mathrm{D}_{2} \mathrm{O}\right.$, $600 \mathrm{MHz}, \delta[p p m]): 4.64-4.53$ (dq, $2 \mathrm{H}) ; 3.93-2.89(\mathrm{~m}, 28 \mathrm{H}) ; 1.41-1.33(\mathrm{~m}, 3 \mathrm{H}) . \mathrm{MS}\left(\mathrm{ESI}^{+}\right): \mathrm{m} / \mathrm{z}(\%)$ : $571.3\left(\mathrm{M}+\mathrm{H}^{+}\right)$, $593.3(\mathrm{M}+\mathrm{Na})$; calculated for $\mathrm{C}_{24} \mathrm{H}_{38} \mathrm{~N}_{6} \mathrm{O}_{10}: 570.26$ 
DOTA.SA.FAPi ( 4 ) [(S)-2,2',2"-(10-(2-((2-((2-((4-)((4-)((2-(2-cyano-4,4-difluoropyrrolidin-1-yl)-2-oxoethyl)carbamoyl)quinolin-6-yl)oxy)butyl)amino)-3,4-dioxocyclobut-1-en-1-yl)amino)ethyl)amino)-2oxoethyl)-1,4,7,10-tetraazacyclododecane-1,4,7-triyl)triacetic acid]

Coupling of DOTA.SA 2 (10.3 mg; $17.5 \mu \mathrm{mol})$ and $\mathrm{NH}_{2}$-FAPi $3(11.4 \mathrm{mg} ; 26.3 \mu \mathrm{mol})$ to form DOTA.SA.FAPi 4 was performed by amidation at pH 9 in $500 \mu \mathrm{L} 0.5 \mathrm{M} \mathrm{Na}_{2} \mathrm{HPO}_{4}$ phosphate buffer at room temperature. The reaction was shaken for 12 h. DOTA.SA.FAPi 4 was isolated via HPLC purification (Phenomenex® Luna ${ }^{\circledR} 10 \mu \mathrm{m} \mathrm{C18}(2) 100 \AA$ ) with a linear gradient condition of $15-20 \% \mathrm{MeCN}(+0,1 \% \mathrm{TFA}) / 85-80 \%$ Water $(+0,1 \%$ TFA) in 20 min with a $5 \mathrm{~mL} / \mathrm{min}$ flow. After lyophilization the product was obtained as yellow powder (12.2 mg; $12.7 \mu \mathrm{mol}, 73 \%)$. MS $\left(\mathrm{ESI}^{+}\right)$: $\mathrm{m} / \mathrm{z}(\%)$ : $956.4\left(\mathrm{M}+\mathrm{H}^{+}\right), 978.4(\mathrm{M}+\mathrm{Na})$; calculated for $\mathrm{C}_{43} \mathrm{H}_{55} \mathrm{~F}_{2} \mathrm{~N}_{11} \mathrm{O}_{12}: 955.40$

\section{Inhibitory Potency Determination}

Enzymes: A gateway-entry clone for human FAP was purchased from Dharmacon (Accession number DQ891423) and the human secretion signal was replaced with the HoneyBee mellitin secretion signal. For transfection and expression of FAP in Sf9 insect cells, the C-terminal BaculoDirect kit from LifeTechnologies was used. The enzyme was purified from the supernatant of the insect cells using immobilized Ni-chelating chromatography (GE healthcare, Diegem, Belgium), followed by anion-exchange chromatography using a $1 \mathrm{~mL}$ HiTrap Q (GE healthcare, Diegem, Belgium). Human recombinant PREP was expressed in BL21(DE3) cells and purified using immobilized Co-chelating chromatography (GE healthcare) followed by anion-exchange chromatography on a $1 \mathrm{ml}$ Mono Q column (GE healthcare).

FAP: $I_{50}$ measurements of the inhibitors were carried out using Z-Gly-Pro-7-amino-4-methylcoumarine (AMC) (Bachem, Switzerland) as the substrate at a concentration of $50 \mu \mathrm{M}$ at pH $8(0.05 \mathrm{M} \mathrm{Tris}-\mathrm{HCl}$ buffer with $0.1 \%$ glycerol, $1 \mathrm{mg} / \mathrm{mL} \mathrm{BSA}$ and $140 \mathrm{mM} \mathrm{NaCl}$ ). Eight concentrations of inhibitors were tested. The final DMSO concentration was kept constant during the experiment to exclude any solvent effects. Inhibitors were pre-incubated with the enzyme for 15 minutes at $37^{\circ} \mathrm{C}$, afterwards the substrate was added and the velocities of AMC release were measured kinetically at $\lambda_{\mathrm{ex}}=380 \mathrm{~nm}, \lambda_{\mathrm{em}}=465 \mathrm{~nm}$ for at least 10 minutes at $37^{\circ} \mathrm{C}$. The Infinite 200 (Tecan Group Ltd.) micro-titer plate reader and the Magellan software were used for measurement and data processing respectively.

\section{Note}

a slightly different protocol, involving a different FAP substrate (Ala-Pro-pNA), was used to determine the originally published FAP IC $5_{50}$-value for reference UAMC1110 $(3.2+/-0.4 \mathrm{nM})$. This accounts for the nonidentical value published here.

PREP: $\mathrm{IC}_{50}$ measurements of the inhibitors were carried out using $\mathrm{N}$-succinyl-Gly-Pro-AMC (Bachem, Switzerland) as the substrate at a concentration of $250 \mu \mathrm{M}$ at pH 7.4 (0.1 M K-phosphate, 1 mM EDTA, $1 \mathrm{mM}$ DTT). Eight concentrations of inhibitors were tested. The final DMSO concentration is kept 
constant during the experiment to exclude any effects. Inhibitors were pre-incubated with the enzyme for 15 minutes at $37^{\circ} \mathrm{C}$, afterwards the substrate was added and the velocities of AMC release were measured kinetically at $\lambda_{\mathrm{ex}}=380 \mathrm{~nm}, \lambda_{\mathrm{em}}=465 \mathrm{~nm}$ for at least 10 minutes at $37^{\circ} \mathrm{C}$. The Infinite 200 (Tecan Group Ltd.) micro-titer plate reader and the Magellan software were used for measurement and data processing, respectively.

The data were fitted using a non-linear fit model in GraFit 7 software, according to the following equation:

$$
y=\frac{\text { range }}{1+\left(\frac{x}{I C_{50}}\right)^{s}}
$$

where $y$ is the value of the residual enzymatic activity compared to a non-inhibited sample, $x$ is the final inhibitor concentration in the assay, $s$ is the slope factor and the $\mathrm{IC}_{50}$ is the half maximal inhibitory concentration.

\section{Synthesis Of DATA ${ }^{5 m}$.SA.FAPi}

DATA ${ }^{5 m}$-en [1,4-Di(tert-butylacetate)-6-((5-(2-((tert-butoxy-carbonyl)aminoethyl)amino)-5-oxopentyl)-6(amino(methyl)-tert-butylacetate)-perhydro-1,4-diazepane] (6)

5 (100 mg; $0.18 \mathrm{mmol}$ ) was added to $1 \mathrm{~mL}$ dry MeCN, HATU (66.3 mg; $0.18 \mathrm{mmol}), \mathrm{HOBt}$ (70.9 mg; $0.53 \mathrm{mmol})$ and DIPEA $(89.3 \mu \mathrm{L} ; 0.53 \mathrm{mmol})$ were added and stirred for $1 \mathrm{~h}$ at room temperature. $N$-bocethylenediamine ( $56.1 \mathrm{mg} ; 0.35 \mathrm{mmol}$ ) was added to the solution and stirred overnight. After completion of the reaction, the solution was concentrated under vacuum and the residue was purified by column chromatography $\left(\mathrm{CHCl}_{3} / \mathrm{MeOH}, 20: 1, \mathrm{Rf}=0.23\right)$. The product was obtained as yellow oil $(114 \mathrm{mg}$; $0.16 \mathrm{mmol} ; 91 \%) .{ }^{1} \mathrm{H}-\mathrm{NMR}$ (DMSO, $400 \mathrm{MHz}, \delta$ [ppm]): 3.36 (s, $\left.2 \mathrm{H}\right) ; 3.23$ (s, $\left.4 \mathrm{H}\right) ; 3.07-3.01$ (m, $2 \mathrm{H}$ ); 2.97-2.91 (m, $2 \mathrm{H}) ; 2.79$ (d, J = 13.7 Hz, $2 \mathrm{H}) ; 2.72-2.67$ (m, $2 \mathrm{H}) ; 2.59-2.54(\mathrm{~m}, 2 \mathrm{H}) ; 2.51$ (d, J = $13.7 \mathrm{~Hz}$, $2 \mathrm{H}) ; 2.17(\mathrm{~s}, 3 \mathrm{H}) ; 2.03(\mathrm{t}, 2 \mathrm{H}) ; 1.45-1.41(\mathrm{~m}, 4 \mathrm{H}) ; 1.40(\mathrm{~s}, 18 \mathrm{H}) ; 1.39(\mathrm{~s}, 9 \mathrm{H}) ; 1.37(\mathrm{~s}, 9 \mathrm{H}) ; 1.22-1.18(\mathrm{~m}$, $2 \mathrm{H}) .{ }^{13} \mathrm{C}-\mathrm{NMR}\left(\mathrm{CDCl}_{3}, 100 \mathrm{MHz}, \delta\right.$ [ppm]): 172.25 (s); 171.72 (s); 170.28 (s); 169.58 (s); 155.62 (s); 80.19 (s); 80.08 (s); 77.63 (s); 62.37 (s); 61.87 (s); 61.73 (s); 58.72 (s); 56.06 (s); 51.50 (s); 37.10 (s); 35.55 (s); 28.24 (s); 27.87 (s); 27.77 (s); 26.11 (s); 25.50 (s); 21.55 (s). MS (ESI $): m / z(\%): 714.4\left(\mathrm{M}+\mathrm{H}^{+}\right) ; 736.5$ (M $+\mathrm{Na}^{+}$); calculated for $\mathrm{C}_{36} \mathrm{H}_{67} \mathrm{~N}_{5} \mathrm{O}_{9}: 713.49$

DATA $^{5 m}$.SA [1,4-Di(acetate)-6-((5-(2-((2-ethoxy-3,4-dioxo-cyclobut-1-en-1yl)aminoethyl)amino)-5-oxopentyl)-6-(amino(methyl)-acetate)-perhydro-1,4-diazepane] (7)

6 (100 mg; $0.14 \mathrm{mmol})$ was dissolved in DCM/TFA (1:1; vol \%) and stirred for 3 hours. After complete deprotection of the tert-butyl groups, the solution was concentrated under vacuum and $3 \mathrm{~mL} 0.5 \mathrm{M}$ phosphate buffer $\mathrm{pH} 7$ was added to the residue. After adding 3,4-diethoxycyclobut-3-ene-1,2-dione $(61.7 \mu \mathrm{L} ; 0.42 \mathrm{mmol})$ to the solution, the $\mathrm{pH}$ was adjusted again to $\mathrm{pH} 7$ with $1 \mathrm{M} \mathrm{NaOH}$ and stirred 
overnight at room temperature. After completion, the reaction solution was purified by HPLC (Phenomenex ${ }^{\circledR}$ Luna $\left.{ }^{\circledR} 10 \mu \mathrm{m} \mathrm{C18}(2) 100 \AA\right)$ with a linear gradient condition of $8-12 \% \operatorname{MeCN}(+0,1 \%$ TFA) $/ 92-88 \%$ Water (+0,1\% TFA) in 20 min with a $5 \mathrm{~mL} / \mathrm{min}$ flow. After lyophilization the product was obtained as white powder (24.8 mg; $43.6 \mu \mathrm{mol}, 31 \%) .{ }^{1} \mathrm{H}-\mathrm{NMR}\left(\mathrm{D}_{2} \mathrm{O}, 600 \mathrm{MHz}, \delta[\mathrm{ppm}]\right): 4.73-4.66(\mathrm{~m}$, $2 \mathrm{H}) ; 3.79$ (s, $2 \mathrm{H}) ; 3.70$ (s, $4 \mathrm{H}), 3.67-3.47(\mathrm{~m}, 6 \mathrm{H}) ; 3.39-3.22(\mathrm{~m}, 6 \mathrm{H}) ; 2.98(\mathrm{~d}, \mathrm{~J}=8.7 \mathrm{~Hz}, 3 \mathrm{H}) ; 2.22(\mathrm{t}$, $2 \mathrm{H}) ; 1.71-1.68$ (m, $2 \mathrm{H}) ; 1.53-1.48(\mathrm{~m}, 2 \mathrm{H}) ; 1.43-1.38(\mathrm{~m}, 2 \mathrm{H}) ; 1.35-1.29(\mathrm{~m}, 2 \mathrm{H}) .{ }^{13} \mathrm{C}-\mathrm{NMR}\left(\mathrm{D}_{2} \mathrm{O}\right.$, $150 \mathrm{MHz}, \delta$ [ppm]): 188.70 (s); 183.25 (s); 177.21 (s); 176.42 (s); 173.82 (s); 170.00 (s); 117.19 (s); 115.26 (s); 70.66 (s); 68.77 (s); 54.14 (s); 43.89 (s); 39.22 (s); 37.76 (s); 35.09 (s); 29.53 (s); 25.69 (s); 25.54 (s); 22.09 (s); 15.03 (s); 14.94 (s). MS (ESI $\left.{ }^{+}\right): \mathrm{m} / \mathrm{z}(\%): 570.3\left(\mathrm{M}+\mathrm{H}^{+}\right) ; 593.3\left(\mathrm{M}+\mathrm{Na}^{+}\right)$; calculated for $\mathrm{C}_{25} \mathrm{H}_{39} \mathrm{~N}_{5} \mathrm{O}_{10}: 569.27$

DATA ${ }^{5 m}$.SA.FAPi (8) [(S)-2,2'-(6-((carboxymethyl)(methyl)amino)-6-(5-((2-)((2-)(4-((4-)((2-(2-cyano-4,4difluoropyrrolidin-1-yl)-2-oxoethyl)carbamoyl)quinolin-6-yl)oxy)butyl)amino)-3,4-dioxocyclobut-1-en-1yl)amino)ethyl)amino)-5-oxopentyl)-1,4-diazepane-1,4-diyl)diacetic acid]

DATA ${ }^{5 \mathrm{~m}}$.SA 7 (8.7 mg, $\left.15.3 \mu \mathrm{mol}\right)$ and $\mathrm{NH}_{2}$-FAPi $3(19.8 \mathrm{mg}, 45.9 \mu \mathrm{mol})$ were reacted to form DATA $^{5 \mathrm{~m}}$.SA.FAPi 8 via amidation at pH 9 in $500 \mu \mathrm{L} 0.5 \mathrm{M} \mathrm{Na}_{2} \mathrm{HPO}_{4}$ phosphate buffer at room temperature stirred overnight. DATA ${ }^{5 \mathrm{~m}}$.SA.FAPi was isolated via HPLC purification (Phenomenex ${ }^{\circledR}$ Luna ${ }^{\circledR}$ $10 \mu \mathrm{m} \mathrm{C18(2)} 100 \AA$ ) with a linear gradient condition of $18-20 \% \mathrm{MeCN}(+0,1 \%$ TFA)/82 - 80\% Water (+ $0,1 \%$ TFA) in $20 \mathrm{~min}$. The product was obtained as yellowish powder (6.2 mg, $6.5 \mu \mathrm{mol} ; 42 \%)$. MS $\left(\mathrm{ESI}^{+}\right)$: $\mathrm{m} / \mathrm{z}(\%)$ : $955.4\left(\mathrm{M}+\mathrm{H}^{+}\right)$; calculated for $\mathrm{C}_{44} \mathrm{H}_{56} \mathrm{~F}_{2} \mathrm{~N}_{10} \mathrm{O}_{12}: 954.40$

\section{${ }^{\text {nat }} \mathrm{Ga} /{ }^{\text {nat }}$ Lu-complexes of DOTA.SA.FAPi}

The ${ }^{\text {nat }}$ Ga-metallated species [ ${ }^{\text {nat }}$ Ga]Ga-DOTA.SA.FAPi was obtained after treatment of DOTA.SA.FAPi (5.2 mg; $5.4 \mu \mathrm{mol}$ ) with stoichiometric amount (1 eq) of $10 \mathrm{mM}{ }^{\text {nat }} \mathrm{Ga}\left(\mathrm{NO}_{3}\right)_{2}$ in $1 \mathrm{~mL} 0.2 \mathrm{M}$ AmAc buffer $\mathrm{pH} 4.5$ shaken for $3 \mathrm{~h}$ at $80^{\circ} \mathrm{C}$. Complexation was confirmed by ESI-MS and HPLC-purification was performed (Phenomenex® Synergi ${ }^{\circledR} 10 \mu \mathrm{m}(\mathrm{C} 18) 100 \AA$ (250 mm $\left.\subseteq 10 \mathrm{~mm}, 10 \mu \mathrm{m}\right)$, linear gradient of 5$95 \% \operatorname{MeCN}(+0,1 \%$ TFA) $/ 95-5 \%$ Water (+0,1\% TFA) in $10 \mathrm{~min}$. The product was obtained as yellowish powder (4.6 mg, $4.5 \mu \mathrm{mol} ; 83 \%)$. MS $\left(\mathrm{ESI}^{+}\right): \mathrm{m} / \mathrm{z}(\%): 1022.2\left(\mathrm{M}+\mathrm{H}^{+}\right), 1044.2(\mathrm{M}+\mathrm{Na})$; calculated for $\mathrm{C}_{43} \mathrm{H}_{53} \mathrm{~F}_{2} \mathrm{GaN}_{11} \mathrm{O}_{12}: 1021.30$

The ${ }^{\text {nat }}$ Lu-metallated species [ ${ }^{\text {nat }}$ Lu]Lu-DOTA.SA.FAPi was obtained after treatment of DOTA.SA.FAPi (6.0 mg; $6.3 \mu \mathrm{mol}$ ) with stoichiometric amount (1 eq) of $1 \mathrm{mM}^{\text {nat }} \mathrm{LuCl}_{3}$ in $1 \mathrm{~mL} 0.2 \mathrm{M} \mathrm{AmAc}$ buffer pH 4.5 shaken for $3 \mathrm{~h}$ at $80^{\circ} \mathrm{C}$. Complexation was confirmed by ESI-MS and HPLC purification was done analogously to the gallium species. The product was obtained as yellowish powder $(5.5 \mathrm{mg}, 4.9 \mu \mathrm{mol}$; 77\%). MS $\left(\mathrm{ESI}^{+}\right): \mathrm{m} / \mathrm{z}(\%): 1028.3\left(\mathrm{M}+\mathrm{H}^{+}\right), 1051.2(\mathrm{M}+\mathrm{Na})$; calculated for $\mathrm{C}_{43} \mathrm{H}_{52} \mathrm{~F}_{2} \mathrm{LuN}_{11} \mathrm{O}_{12}: 1027.32$

\section{${ }^{\text {nat }}$ Ga-complexes of DATA ${ }^{5 m}$.SA.FAPi}


The ${ }^{\text {nat }}$ Ga-metallated species [ $\left.{ }^{\text {nat }} G a\right]$ Ga-DATA ${ }^{5 m}$.SA.FAPi was obtained after treatment of DATA $^{5 \mathrm{~m}}$.SA.FAPi $(7.2 \mathrm{mg} ; 7.5 \mu \mathrm{mol})$ with stoichiometric amount of ${ }^{\text {nat }} \mathrm{Ga}\left(\mathrm{NO}_{3}\right)_{2}$ in $1 \mathrm{~mL} 0.2 \mathrm{M} \mathrm{AmAc}$ buffer $\mathrm{pH} 4.5$ shaken for $2 \mathrm{~h}$ at $25^{\circ} \mathrm{C}$. Complexation was confirmed by ESI-MS and HPLC-purification was performed (Phenomenex ${ }^{\circledR}$ Luna ${ }^{\circledR} 10 \mu \mathrm{m}$ (C18) $100 \AA$ (250 mm $\left.\subseteq 10 \mathrm{~mm}, 10 \mu \mathrm{m}\right)$, linear gradient of 5$95 \% \operatorname{MeCN}(+0,1 \%$ TFA) $/ 95-5 \%$ Water (+0,1\% TFA) in $10 \mathrm{~min}$. The product was obtained as yellowish powder (4.4 mg, $4.3 \mu \mathrm{mol} ; 57 \%)$. MS $\left(\mathrm{ESI}^{+}\right)$: $\mathrm{m} / \mathrm{z}(\%): 1021.3\left(\mathrm{M}+\mathrm{H}^{+}\right), 1043.2(\mathrm{M}+\mathrm{Na})$; calculated for $\mathrm{C}_{44} \mathrm{H}_{53} \mathrm{~F}_{2} \mathrm{GaN}_{10} \mathrm{O}_{12}: 1020.31$

\section{Inhibitory potency determination}

Enzymes: A gateway-entry clone for human FAP was purchased from Dharmacon (Accession number DQ891423) and the human secretion signal was replaced with the HoneyBee mellitin secretion signal. For transfection and expression of FAP in Sf9 insect cells, the C-terminal BaculoDirect kit from LifeTechnologies was used. The enzyme was purified from the supernatant of the insect cells using immobilized Ni-chelating chromatography (GE healthcare, Diegem, Belgium), followed by anion-exchange chromatography using a $1 \mathrm{~mL}$ HiTrap Q (GE healthcare, Diegem, Belgium). Human recombinant PREP was expressed in BL21(DE3) cells and purified using immobilized Co-chelating chromatography (GE healthcare) followed by anion-exchange chromatography on a $1 \mathrm{ml}$ Mono Q column (GE healthcare).

FAP: $I_{50}$ measurements of the inhibitors were carried out using Z-Gly-Pro-7-amino-4-methylcoumarine (AMC) (Bachem, Switzerland) as the substrate at a concentration of $50 \mu \mathrm{M}$ at pH $8(0.05 \mathrm{M} \mathrm{Tris-HCl}$ buffer with $0.1 \%$ glycerol, $1 \mathrm{mg} / \mathrm{mL}$ BSA and $140 \mathrm{mM} \mathrm{NaCl}$ ). Eight concentrations of inhibitors were tested. The final DMSO concentration was kept constant during the experiment to exclude any solvent effects. Inhibitors were pre-incubated with the enzyme for 15 minutes at $37^{\circ} \mathrm{C}$, afterwards the substrate was added and the velocities of AMC release were measured kinetically at $\lambda_{\mathrm{ex}}=380 \mathrm{~nm}, \lambda_{\mathrm{em}}=465 \mathrm{~nm}$ for at least 10 minutes at $37^{\circ} \mathrm{C}$. The Infinite 200 (Tecan Group Ltd.) micro-titer plate reader and the Magellan software were used for measurement and data processing respectively.

Note: a slightly different protocol, involving a different FAP substrate (Ala-Pro-pNA), was used to determine the originally published FAP IC ${ }_{50}$-value for reference UAMC1110 $(3.2+/-0.4 \mathrm{nM})$. This accounts for the non-identical value published here.

PREP: IC ${ }_{50}$ measurements of the inhibitors were carried out using $\mathrm{N}$-succinyl-Gly-Pro-AMC (Bachem, Switzerland) as the substrate at a concentration of $250 \mu \mathrm{M}$ at pH 7.4 (0.1 M K-phosphate, 1 mM EDTA, 1 mM DTT). Eight concentrations of inhibitors were tested. The final DMSO concentration is kept constant during the experiment to exclude any effects. Inhibitors were pre-incubated with the enzyme for 15 minutes at $37^{\circ} \mathrm{C}$, afterwards the substrate was added and the velocities of AMC release were measured kinetically at $\lambda_{\mathrm{ex}}=380 \mathrm{~nm}, \lambda_{\mathrm{em}}=465 \mathrm{~nm}$ for at least 10 minutes at $37^{\circ} \mathrm{C}$. The Infinite 200 (Tecan Group Ltd.) micro-titer plate reader and the Magellan software were used for measurement and data processing, respectively. 
The data were fitted using a non-linear fit model in GraFit 7 software, according to the following equation:

$$
y=\frac{\text { range }}{1+\left(\frac{x}{I C_{50}}\right)^{s}}
$$

where $y$ is the value of the residual enzymatic activity compared to a non-inhibited sample, $x$ is the final inhibitor concentration in the assay, $s$ is the slope factor and the $\mathrm{IC}_{50}$ is the half maximal inhibitory concentration.

\section{Radiolabeling And Stability Studies With ${ }^{68} \mathrm{Ga}$}

${ }^{68} \mathrm{Ga}$ was eluted manually utilizing ethanol post-processed ${ }^{68} \mathrm{Ga}$-eluate from a ${ }^{68} \mathrm{Ge} /{ }^{68} \mathrm{Ga}$-generator (ITG Garching, Germany). ${ }^{68} \mathrm{Ga}$ was eluted with $5 \mathrm{~mL} 0.05 \mathrm{M} \mathrm{HCl}$, purification was carried out with $1 \mathrm{~mL} 80 \%$ $\mathrm{EtOH} / 0.15 \mathrm{M} \mathrm{HCl}$ and the $\mathrm{Ga}$ (III) elution from the column with $400 \mu \mathrm{L} 90 \% \mathrm{EtOH} / 0.9 \mathrm{M} \mathrm{HCl}$.[44] The pH of the ${ }^{68} \mathrm{Ga}$-eluate ${ }^{68} \mathrm{Ga}$ was adjusted to $\mathrm{pH} 4.0-4.5$ using $400 \mu \mathrm{L} 1 \mathrm{M}$ AmAc buffer.

Reaction controls for radiochemical purity were executed using radio-TLC (TLC Silica gel $60 \mathrm{~F}_{254}$ Merck) with citrate buffer $\mathrm{pH} 4$ and radio-HPLC using an analytical HPLC 7000 series Hitachi LaChrom with a Phenomenex (Aschaffenburg, Germany) Luna C18 column $(250 \times 4.6 \mathrm{~mm}, 5 \mu)$, linear gradient of $5-95 \%$ MeCN (+ 0,1\% TFA)/ 95 - 5\% Water (+ 0,1\% TFA) in 10 min). TLC's were measured in TLC imager CR-35 Bio Test-Imager from Duerr-ndt (Bietigheim-Bissingen, Germany) with the analysis software AIDA ElysiaRaytest (Straubenhardt, Germany). The citrate TLCs show free radio metal with a $R_{f}$ value of $0.8-0.9$. The labeled complexes are observed at a $R_{f}$ value of $0.1-0.2$.

${ }^{68} \mathrm{Ga}$ stability studies against transmetallation ( $\mathrm{Fe}, \mathrm{Cu}, \mathrm{Ca}, \mathrm{Mg}$ ), transchelation (EDTA, DTPA) as well as in $\mathrm{HS}$, ethanol and saline ( $0.9 \%$ isotone $\mathrm{NaCl}$-solution) were performed. $50 \mu$ of the $\left[{ }^{68} \mathrm{Ga}\right] \mathrm{Ga}$-DOTA.SA.FAPi labeling solution with $>95 \%$ radiochemical purity were added to $1 \mathrm{~mL}$ of the respective media. The measured time points for ${ }^{68} \mathrm{Ga}$ were $15,30,45,60,90,120 \mathrm{~min}$. Human serum (human male AB plasma, USA origin) was bought from Sigma Aldrich, PBS was purchased from Sigma Aldrich and $0.9 \%$ saline from B. Braun Melsungen AG (Melsungen, Germany).

In vivo animal studies and ex vivo biodistributions

After quantitative radiolabeling of $\left[{ }^{68} \mathrm{Ga}\right]$-DOTA.SA.FAPi $(20 \mathrm{nmol})$, the solution was purified via C-18 column (Sep-Pak Light C18, Waters Corporation, Massachusetts, USA). Conditioning of the SPE was performed using $5 \mathrm{ml}$ abs. ethanol and $5 \mathrm{~mL}$ water. Precursor solution was pressed over the SPE and then washed with $5 \mathrm{ml}$ water. Afterwards, the ${ }^{68} \mathrm{Ga}$-labeled precursor was eluted with $1 \mathrm{~mL}$ of 50 vol\% ethanol. 
Finally, the ethanol was evaporated and the tracer was reformulated in $5 \%$ ethanol in saline solution (500 $\mu$ l total volume). The completed solution was used as injection solution.

In vivo tumor model: HT-29 (human colon adenocarcinoma, ATCC, Rockville, Maryland) cells were routinely cultured in Dulbecco's Modified Eagle Medium supplemented with $10 \%$ heat inactivated foetal bovine serum (FBS), 2 mM glutamine, 1\% sodium pyruvate and 1\% penicillin/streptomycin (Gibco, Life technologies). After detaching the cells, the number of viable cells was counted with the automated Muse $^{\text {TM }}$ Cell Analyzer (Merck Millipore). For the HT-29 subcutaneous model, $10.10^{6}$ viable cells, suspended in $100 \mu \mathrm{lPBS}$, were inoculated in the right hind leg of female 6-week-old $\mathrm{CD} 1^{-/-}$Foxn1nu mice $(n=3)$, obtained from Charles River Laboratories (L'Arbresle, France). The animals were kept under environmentally controlled conditions ( $12 \mathrm{~h}$ light/dark cycle, $20-24{ }^{\circ} \mathrm{C}$ and $40-70 \%$ relative humidity) with food and water ad libitum. When tumors reached an approximate volume of $400 \mathrm{~mm}^{3}, 3$ mice underwent $\mu \mathrm{PET}$ imaging. All experimental procedures and protocols were performed in accordance with European Directive 86/609/EEC Welfare and Treatment of Animals and were approved by the local ethical commission (2017-070, University of Antwerp, Belgium).

Micro-PET imaging: Micro-PET scans were carried out using an Inveon small-animal PET/CT scanner

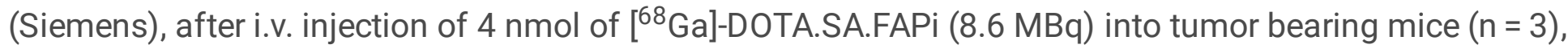
under isoflurane anesthesia ( $5 \%$ for induction, $2 \%$ for maintenance). Static whole-body PET images were acquired 60 min after injection of the radiotracer. Following each PET acquisition, a whole-body CT scan was acquired to obtain the animal's anatomical information individually.

For quantitative analysis, PET data were reconstructed using 3-dimensional ordered subset expectation maximization (OSEM3D, 16 subsets and 2 iterations) and 18 maximum a posteriori (MAP) iterations including scatter and attenuation correction (matrix size, $128 \times 128 \times 159$; voxel size, $0.776 \times 0.776 \times$ $0.776 \mathrm{~mm}$;). Volumes of interest (VOIs) were manually drawn on the PET/CT images using PMOD (version 3.6; PMOD Technologies) to delineate the tumor, heart and muscle.

Ex vivo biodistribution: Immediately after the CT scans, the animals were sacrificed, the blood, tissues and organs were collected, weighed and the radioactivity was measured using an automatic $\gamma$-counter (Wizard $^{2} 2480$, PerkinElmer). Values were expressed as percentage of the injected dose per gram (\%ID/g).

\section{List Of Abbrevations}

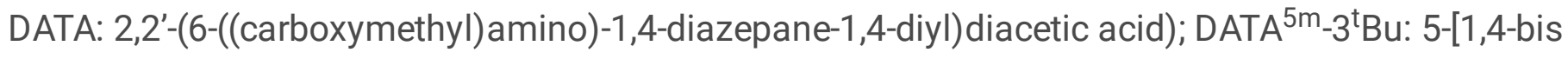
tertbutoxycarbonylmethyl-6-(tert-butoxycarbonylmethyl-methyl-amino)-[1, 4]diazepan-6-yl]-pentanoic acid; DOTA: 1,4,7,10-Tetraazacyclododecane-1,4,7,10-tetraacetic acid; DTPA: cyclohexyldiethylenetriaminepentaacetic acid; EDTA: ethylenediaminetetraacetic acid; FAP: fibroblast activation protein; PREP: prolyl endopeptidase; DPP: dipeptidyl peptidase; CAF: cancer associated fibroblast; $\mathrm{IC}_{50}$ : Half-maximal inhibitory concentration; MIP: maximum intensity projection; PET: positron emission tomography; CT: computed tomography; Boc: tert-Butyloxycarbonyl; ${ }^{\mathrm{B}} \mathrm{Bu}$ : tert-Butyl; ESI: electrospray ionization; HS: human 
serum; HPLC: high-performance liquid chromatography; LC: liquid chromatography; MS: mass spectrometry; AmAc: ammonium acetate; NaAc: natrium acetate; NMR: nuclear magnetic resonance; PBS: phosphate buffered saline; RCY: radiochemical yield; RT: room temperature; SA: squaric acid; SADE: squaric acid diethyl ester; TLC: thin layer chromatography; AMC: Z-Gly-Pro-7-amino-4-methylcoumarine; FBS: foetal bovine serum; p.i.: post injection.

\section{Declarations}

Ethics approval and consent to participate: All experimental procedures and protocols were performed in accordance with European Directive 86/609/EEC Welfare and Treatment of Animals and were approved by the local ethical commission (2017-070, University of Antwerp, Belgium).

Consent for publication: Not applicable.

Availability of data and materials: Data sharing is not applicable to this article as no datasets were generated. Please contact authors for data request.

Competing interests: The authors declare that they have no competing interests.

Funding: No specific funding was received.

Authors contribution: EM carried out the preparative organic and radiochemical synthesis and evaluations, chemical separations, and analytics. Additionally, EM wrote the manuscript. GV carried out the in vitro inhibitory studies and $A B$ is responsible for the expression of FAP and PREP. FE, SDL and EM carried out the labeling for in vivo studies and FE was responsible for analysis of the in vivo and ex vivo data. CV was responsible for the tumor model and has carried out the animal handling and SDB was also involved in the organ/tumor manipulation during the biodistribution determination. EE helped with radiochemical evaluation and LG, BK with organic synthesis. SS, IDM and PVV directed the in vitro inhibitory and in vivo/ ex vivo studies in Antwerp. FR supervised the whole project. All authors read and approved the manuscript.

Acknowledgements: The authors thank the employees and technicians of the nuclear medicine (UZA) and the animal PET-team of the Molecular Imaging Center Antwerp (MICA). An Bracke is supported by the GOA BOF 2015 grant (No. 30729) of the University of Antwerp. Especially thanks to Philippe Joye (MICA) for the in vivo measurements, Jonathan Dewulf and Lucas Beroske (UZA) for helping with ${ }^{68} \mathrm{Ga}$-elution for the in vivo studies.

\section{References}

1. Brennen WN, Isaacs JT, Denmeade SR. Rationale behind targeting fibroblast activation proteinexpressing carcinoma-associated fibroblasts as a novel chemotherapeutic strategy. Mol Cancer Ther. 2012;11:257-66. 
2. Dvořáková P, Bušek P, Knedlík T, Schimer J, Etrych T, Kostka L, et al. Inhibitor-Decorated Polymer Conjugates Targeting Fibroblast Activation Protein. J Med Chem. 2017;60:8385-93.

3. Aertgeerts K, Levin I, Shi L, Snell GP, Jennings A, Prasad GS, et al. Structural and kinetic analysis of the substrate specificity of human fibroblast activation protein a. J Biol Chem. 2005;280:19441-4.

4. Levy MT, McCaughan GW, Abbott CA, Park JE, Cunningham AM, Muller E, et al. Fibroblast activation protein: A cell surface dipeptidyl peptidase and gelatinase expressed by stellate cells at the tissue remodelling interface in human cirrhosis. Hepatology. 1999;29:1768-78.

5. Park JE, Lenter MC, Zimmermann RN, Garin-Chesa P, Old LJ, Rettig WJ. Fibroblast activation protein, a dual specificity serine protease expressed in reactive human tumor stromal fibroblasts. J Biol Chem. 1999;274:36505-12.

6. Edosada CY, Quan C, Wiesmann C, Tran T, Sutherlin D, Reynolds M, et al. Selective inhibition of fibroblast activation protein protease based on dipeptide substrate specificity. J Biol Chem. 2006;281:7437-44.

7. $10.1016 /$ j.cca. 2019.04 .063

Bracke A, Van Elzen R, Van Der Veken P, Augustyns K, De Meester I, Lambeir AM. The development and validation of a combined kinetic fluorometric activity assay for fibroblast activation protein alpha and prolyl oligopeptidase in plasma. Clin Chim Acta [Internet]. Elsevier; 2019;495:154-60. Available from: https://doi.org/10.1016/j.cca.2019.04.063.

8. Hamson EJ, Keane FM, Tholen S, Schilling O, Gorrell MD. Understanding fibroblast activation protein (FAP): Substrates, activities, expression and targeting for cancer therapy. Proteomics - Clin Appl. 2014;8:454-63.

9. Liu R, Li H, Liu L, Yu J, Ren X. Fibroblast activation protein: A potential therapeutic target in cancer. Cancer Biol Ther. 2012;13:123-9.

10. 10.1038/s41573-018-0004-1

Chen X, Song E. Turning foes to friends: targeting cancer-associated fibroblasts. Nat Rev Drug Discov [Internet]. Springer US; 2019;18:99-115. Available from: http://dx.doi.org/10.1038/s41573-018-00041.

11. Jiang G-M, Xu W, Du J, Zhang K-S, Zhang Q-G, Wang X-W, et al. The application of the fibroblast activation protein alpha-targeted immunotherapy strategy. Oncotarget [Internet]. 2016;7. Available from: http://www.oncotarget.com/fulltext/8098.

12. Liu T, Zhou L, Li D, Andl T, Zhang Y. Cancer-associated fibroblasts build and secure the tumor microenvironment. Front Cell Dev Biol. 2019;7:1-14.

13. Zi F, He J, He D, Li Y, Yang L, Cai Z. Fibroblast activation protein a in tumor microenvironment: Recent progression and implications (Review). Mol Med Rep. 2015;11:3203-11.

14. De Vlieghere $E$, Verset L, Demetter P, Bracke M, De Wever O. Cancer-associated fibroblasts as target and tool in cancer therapeutics and diagnostics. Virchows Arch. 2015;467:367-82.

15. Tao L, Huang G, Song H, Chen Y, Chen L. Cancer associated fibroblasts: An essential role in the tumor microenvironment (review). Oncol Lett. 2017;14:2611-20. 
16. Busek P, Mateu R, Zubal M, Kotackova L, Sedo A. Targeting Fibroblast activation protein in cancer Prospects and caveats. Front Biosci - Landmark. 2018;23:1933-68.

17. Scanlan MJ, Raj BKM, Calvo B, Garin-Chesa P, Sanz-Moncasi MP, Healey JH, et al. Molecular cloning of fibroblast activation protein $a$, a member of the serine protease family selectively expressed in stromal fibroblasts of epithelial cancers. Proc Natl Acad Sci U S A. 1994;91:5657-61.

18. Poplawski SE, Lai JH, Li Y, Jin Z, Liu Y, Wu W, et al. Identification of selective and potent inhibitors of fibroblast activation protein and prolyl oligopeptidase. J Med Chem. 2013;56:3467-77.

19. Connolly BA, Sanford DG, Chiluwal AK, Healey SE, Peters DE, Dimare MT, et al. Dipeptide boronic acid inhibitors of dipeptidyl peptidase IV: Determinants of potency and in vivo efficacy and safety. J Med Chem. 2008;51:6005-13.

20. Jansen K, De Winter H, Heirbaut L, Cheng JD, Joossens J, Lambeir AM, et al. Selective inhibitors of fibroblast activation protein (FAP) with a xanthine scaffold. Medchemcomm. 2014;5:1700-7.

21. Jansen K, Heirbaut L, Verkerk R, Cheng JD, Joossens J, Cos P, et al. Extended structure-activity relationship and pharmacokinetic investigation of (4-quinolinoyl)glycyl-2-cyanopyrrolidine inhibitors of fibroblast activation protein (FAP). J Med Chem. 2014;57:3053-74.

22. De Decker A, Vliegen G, Van Rompaey D, Peeraer A, Bracke A, Verckist L, et al. Novel Small MoleculeDerived, Highly Selective Substrates for Fibroblast Activation Protein (FAP). ACS Med Chem Lett. 2019;10:1173-9.

23. Yang X, Nimmagadda S, Rowe S, Slania S, Pomper MG. Imaging and Radiotherapeutics Agents Targeting Fibroblast-Activation Protein-Alpha (FAP-Alpha). Patent. 2019.

24. Loktev A, Lindner T, Mier W, Debus J, Altmann A, Jaeger D, et al. A Tumor-Imaging Method Targeting Cancer-Associated Fibroblasts. J Nucl Med. 2018;59:1423-9.

25. Lindner T, Loktev A, Altmann A, Giesel F, Kratochwil C, Debus J, et al. Development of QuinolineBased Theranostic Ligands for the Targeting of Fibroblast Activation Protein. J Nucl Med. 2018;59:1415-22.

26. Loktev A, Lindner T, Burger EM, Altmann A, Giesel F, Kratochwil C, et al. Development of fibroblast activation protein-targeted radiotracers with improved tumor retention. J Nucl Med. 2019;60:1421-9.

27. Giesel FL, Kratochwil C, Lindner T, Marschalek MM, Loktev A, Lehnert W, et al. ${ }^{68}$ Ga-FAPI PET/CT: Biodistribution and preliminary dosimetry estimate of 2 DOTA-containing FAP-targeting agents in patients with various cancers. J Nucl Med. 2019;60:386-92.

28. Giesel FL, Heussel CP, Lindner T, Röhrich M, Rathke H, Kauczor HU, et al. FAPI-PET/CT improves staging in a lung cancer patient with cerebral metastasis. Eur J Nucl Med Mol Imaging European Journal of Nuclear Medicine Molecular Imaging. 2019;46:1754-5.

29. Kratochwil C, Flechsig P, Lindner T, Abderrahim L, Altmann A, Mier W, et al. ${ }^{68}$ Ga-FAPI PET/CT: Tracer uptake in 28 different kinds of cancer. J Nucl Med. 2019;60:801-5.

30. Wurm FR, Klok HA. Be squared: Expanding the horizon of squaric acid-mediated conjugations. Chem Soc Rev. 2013;42:8220-36. 
31. Ian Storer R, Aciro C, Jones LH. Squaramides. Physical properties, synthesis and applications. Chem Soc Rev. 2011;40:2330-46.

32. Tietze LF, Arlt M, Beller M, Glüsenkamp K -H, Jähde E, Rajewsky MF. Squaric Acid Diethyl Ester: A New Coupling Reagent for the Formation of Drug Biopolymer Conjugates. Synthesis of Squaric Acid Ester Amides and Diamides. Chem Ber. 1991;124:1215-21.

33. Yoganathan S, Sit CS, Vederas JC. Chemical synthesis and biological evaluation of galliderminsiderophore conjugates. Org Biomol Chem. 2011;9:2133-41.

34. Rudd SE, Roselt P, Cullinane C, Hicks RJ, Donnelly PS. A desferrioxamine B squaramide ester for the incorporation of zirconium-89 into antibodies. Chem Commun. 2016;52:11889-92.

35. Greifenstein L, Grus T, Nagel J, Sinnes JP, Rösch F. Synthesis and labeling of a squaric acid containing PSMA-inhibitor coupled to AAZTA ${ }^{5}$ for versatile labeling with ${ }^{44} \mathrm{Sc},{ }^{64} \mathrm{Cu},{ }^{68} \mathrm{Ga}$ and ${ }^{177} \mathrm{Lu}$. Appl Radiat Isot. 2019;108867.

36. Greifenstein L, Engelbogen N, Lahnif H, Sinnes J-P, Bergmann R, Bachmann M, et al. Synthesis, labeling and preclinical evaluation of a squaric acid containing PSMA-inhibitor labeled with ${ }^{68} \mathrm{Ga}-\mathrm{a}$ comparison with PSMA-11 and PSMA-617. ChemMedChem. 2020;1-11.

37. Price EW, Orvig C. Matching chelators to radiometals for radiopharmaceuticals. Chem Soc Rev. 2014;43:260-90.

38. Seemann J, Waldron B, Parker D, Roesch F. DATATOC: a novel conjugate for kit-type ${ }^{68} \mathrm{Ga}$ labelling of TOC at ambient temperature. EJNMMI Radiopharm Chem. 2017;1:4.

39. Seemann J, Waldron BP, Roesch F, Parker D. Approaching "kit-type" labelling with ${ }^{68} \mathrm{Ga}$ : The DATA chelators. ChemMedChem. 2015;10:1019-26.

40. Sinnes JP, Nagel J, Waldron BP, Maina T, Nock BA, Bergmann RK, et al. Instant kit preparation of ${ }^{68} \mathrm{Ga}$-radiopharmaceuticals via the hybrid chelator DATA: clinical translation of [ $\left.{ }^{68} \mathrm{Ga}\right] \mathrm{Ga}-\mathrm{DATA}-\mathrm{TOC}$. EJNMMI Res. 2019;9.

41. Quiñonero $D$, Frontera $A$, Ballester $P$, Deyà $P M$. A theoretical study of aromaticity in squaramide and oxocarbons. Tetrahedron Lett. 2000;41:2001-5.

42. Henry LR, Lee HO, Lee JS, Klein-Szanto A, Watts P, Ross EA, et al. Clinical implications of fibroblast activation protein in patients with colon cancer. Clin Cancer Res. 2007;13:1736-41.

43. Cheng JD, Dunbrack RL, Valianou M, Rogatko A, Alpaugh RK, Weiner LM. Promotion of tumor growth by murine fibroblast activation protein, a serine protease, in an animal model. Cancer Res. 2002;62:4767-72.

44. Eppard E, Wuttke M, Nicodemus PL, Ros̈ch F. Ethanol-based post-processing of generator-derived ${ }^{68} \mathrm{Ga}$ Toward kit-type preparation of ${ }^{68} \mathrm{Ga}$-radiopharmaceuticals. J Nucl Med. 2014;55:1023-8.

\section{Figures}




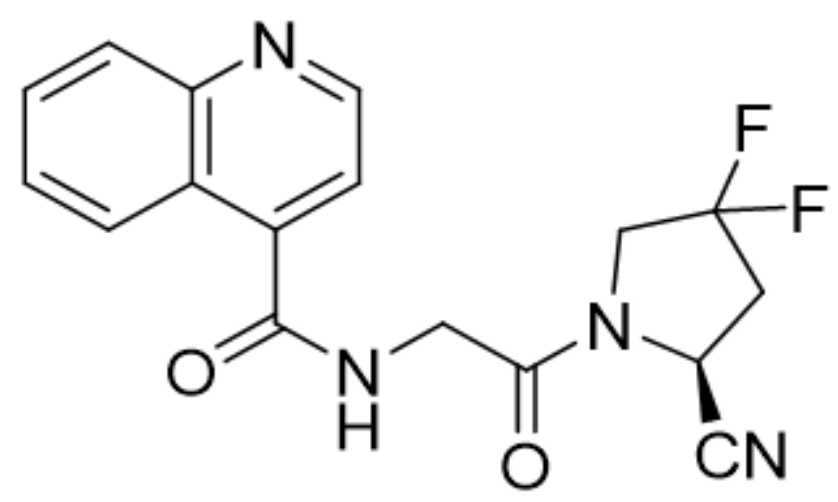

\section{UAMC1110}

Figure 1

FAP-inhibitor lead structure UAMC 1110 


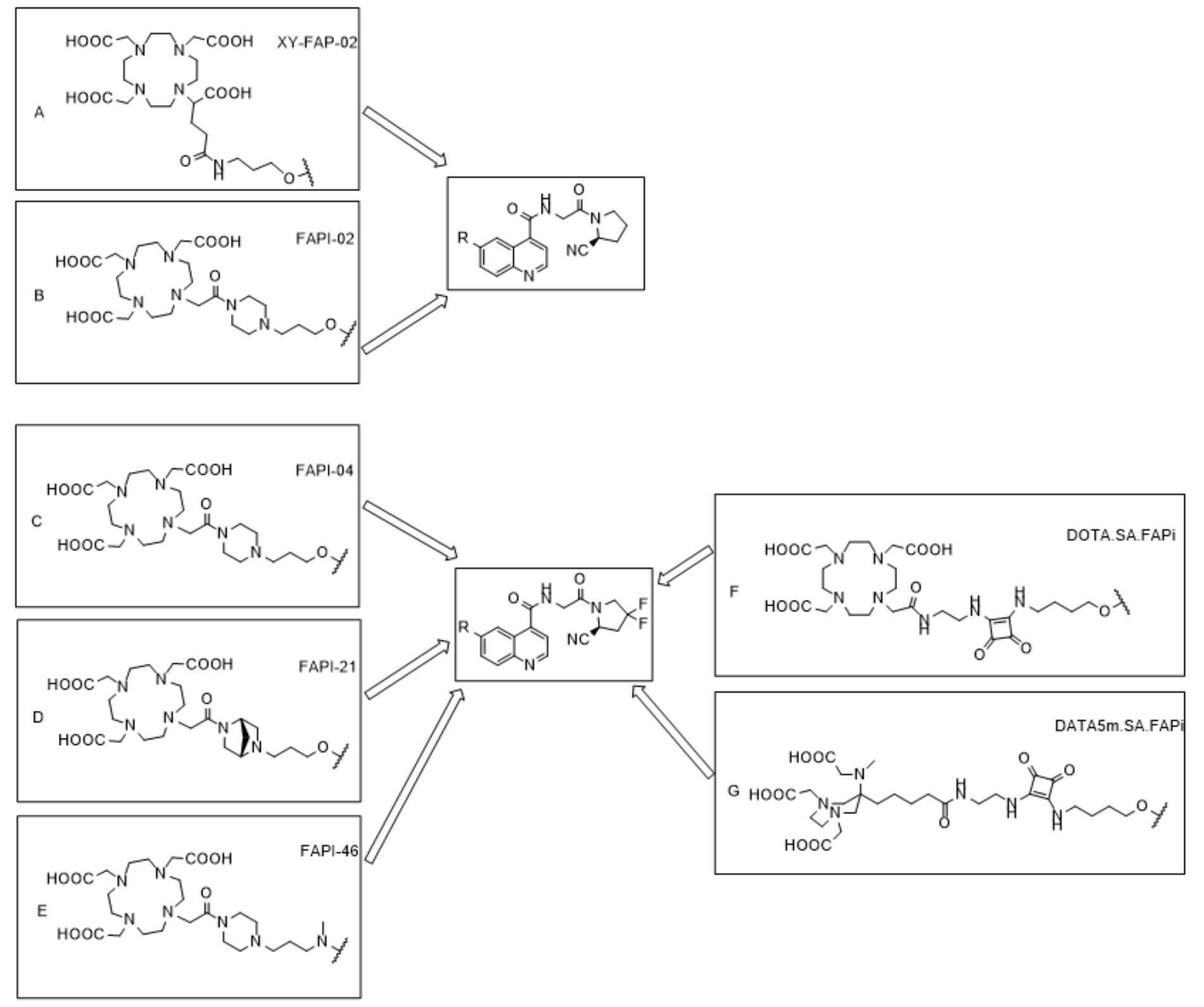

\section{Figure 2}

Chelator-linker conjugates coupled with UAMC1110. A) XY-FAP-02; B) FAPI-02; C) FAPI-04; D) FAPI-21; E) FAPI-46; F) DOTA.SA.FAPi; G) DATA5m.SA.FAPi. 


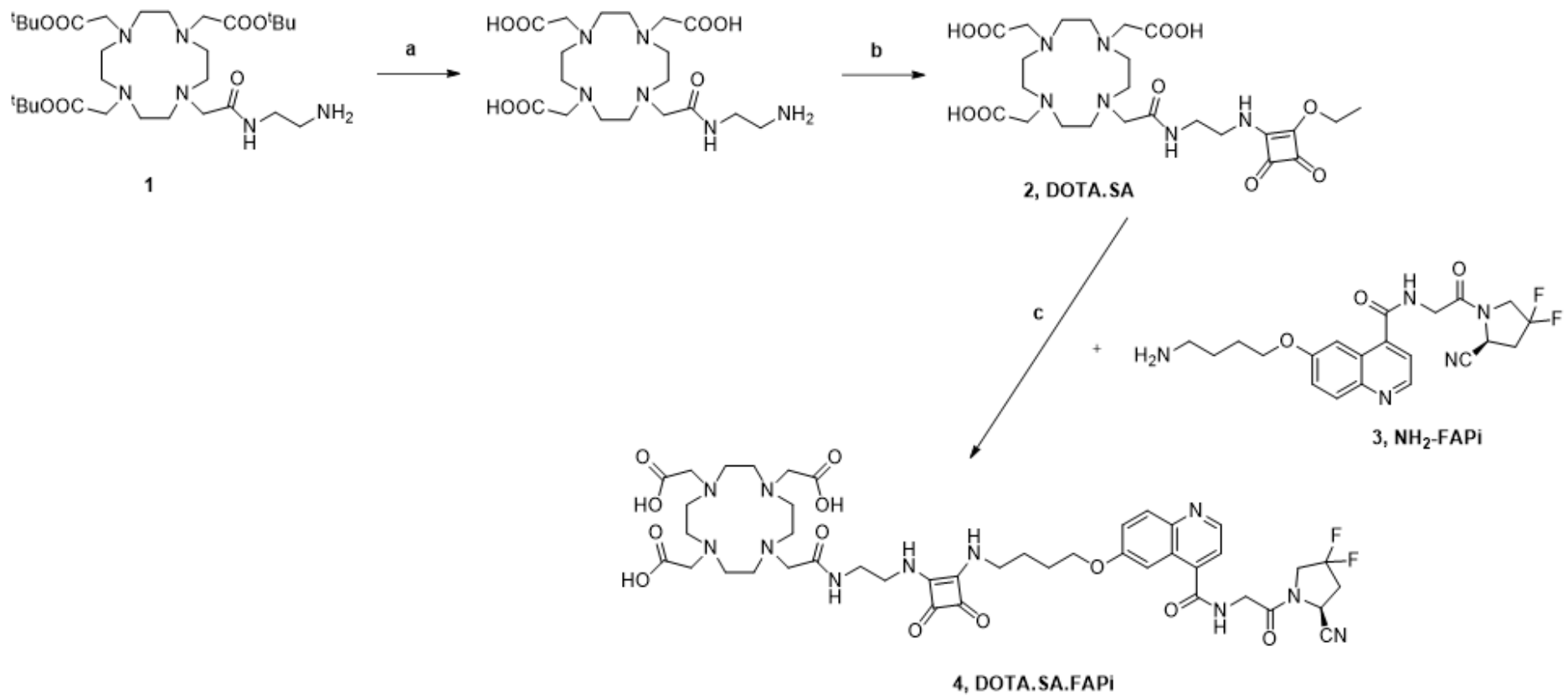

\section{Figure 3}

Synthesis scheme of DOTA.SA.FAPi 4: (a) 80 \% TFA in DCM; (b) 3,4-diethoxycyclobut-3-ene-1,2-dione, Phosphate-buffer pH 7, $1 \mathrm{M} \mathrm{NaOH}$; (c) Phosphate-buffer $\mathrm{pH}$ 9, $1 \mathrm{M} \mathrm{NaOH}$.
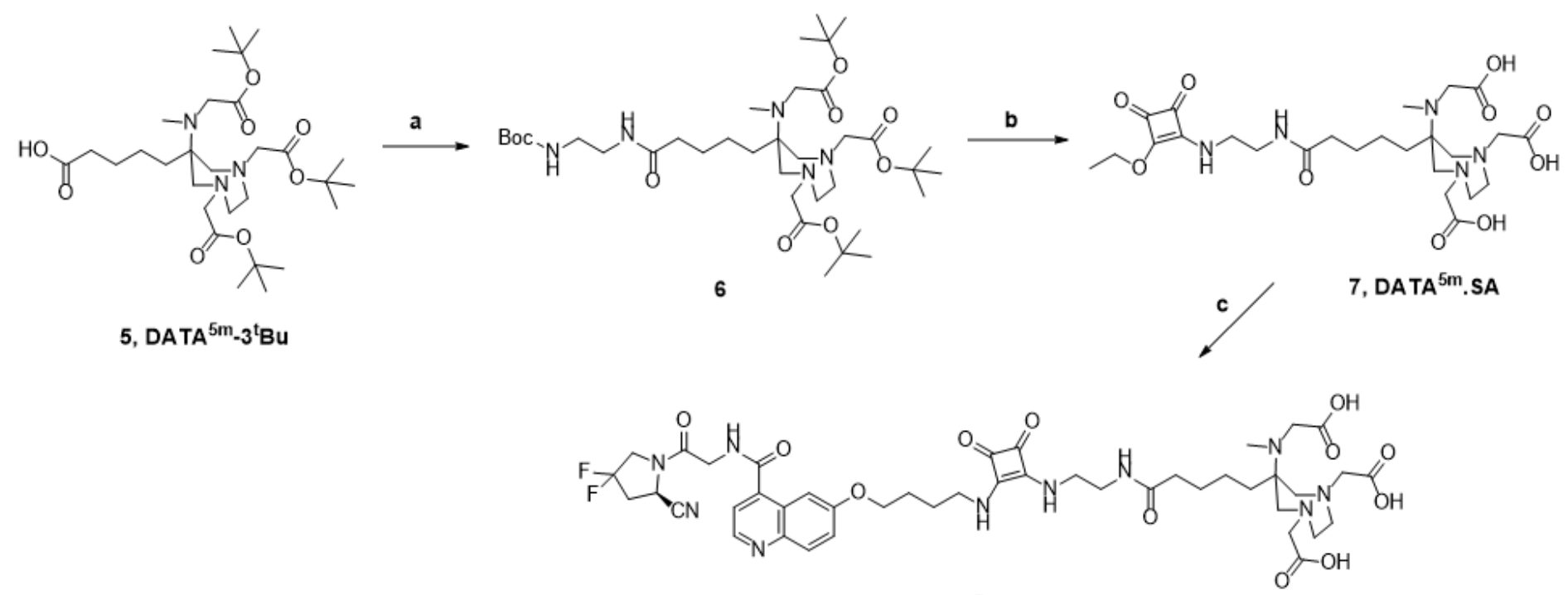

8, DATA ${ }^{5 m}$.SA.FAPI

\section{Figure 4}

Synthesis scheme of DATA5m.SA.FAPi 8: (a) N-Boc-ethylenediamine, HATU, HOBt, DIPEA, MeCN; (b) (i) 80 \% TFA in DCM; (ii) 3,4-diethoxycyclobut-3-ene-1,2-dione, phosphate buffer pH 7, $1 \mathrm{M} \mathrm{NaOH}$; (c) 3, phosphate-buffer $\mathrm{pH}$ 9, $1 \mathrm{M} \mathrm{NaOH}$. 


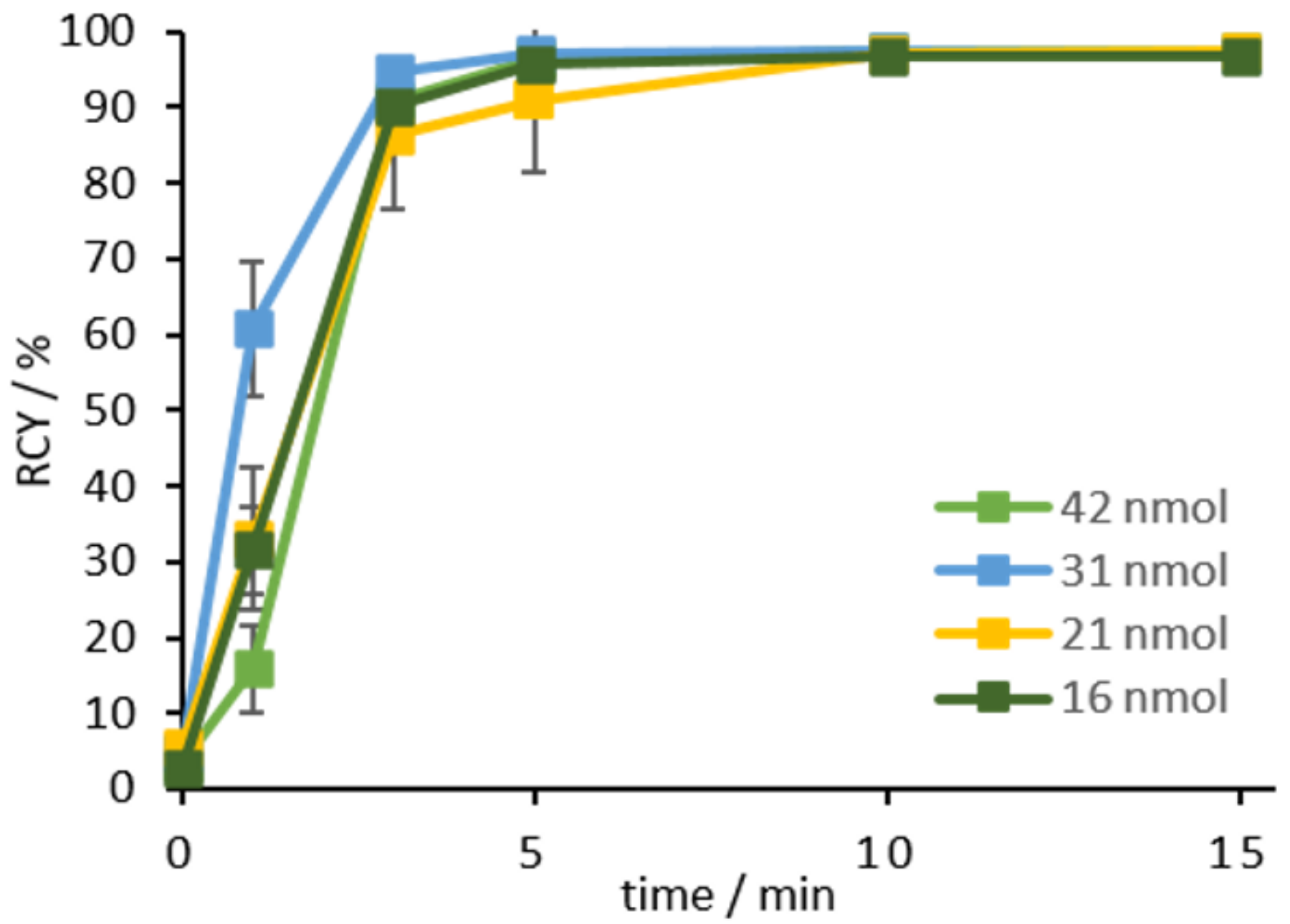

Figure 5

Radiolabeling kinetics for various amounts of [68Ga]Ga-DOTA.SA.FAPi complex at $95^{\circ} \mathrm{C}$, precursor amounts $>15 \mathrm{nmol}$ result in RCY $>97 \%$ after $15 \mathrm{~min}$. 


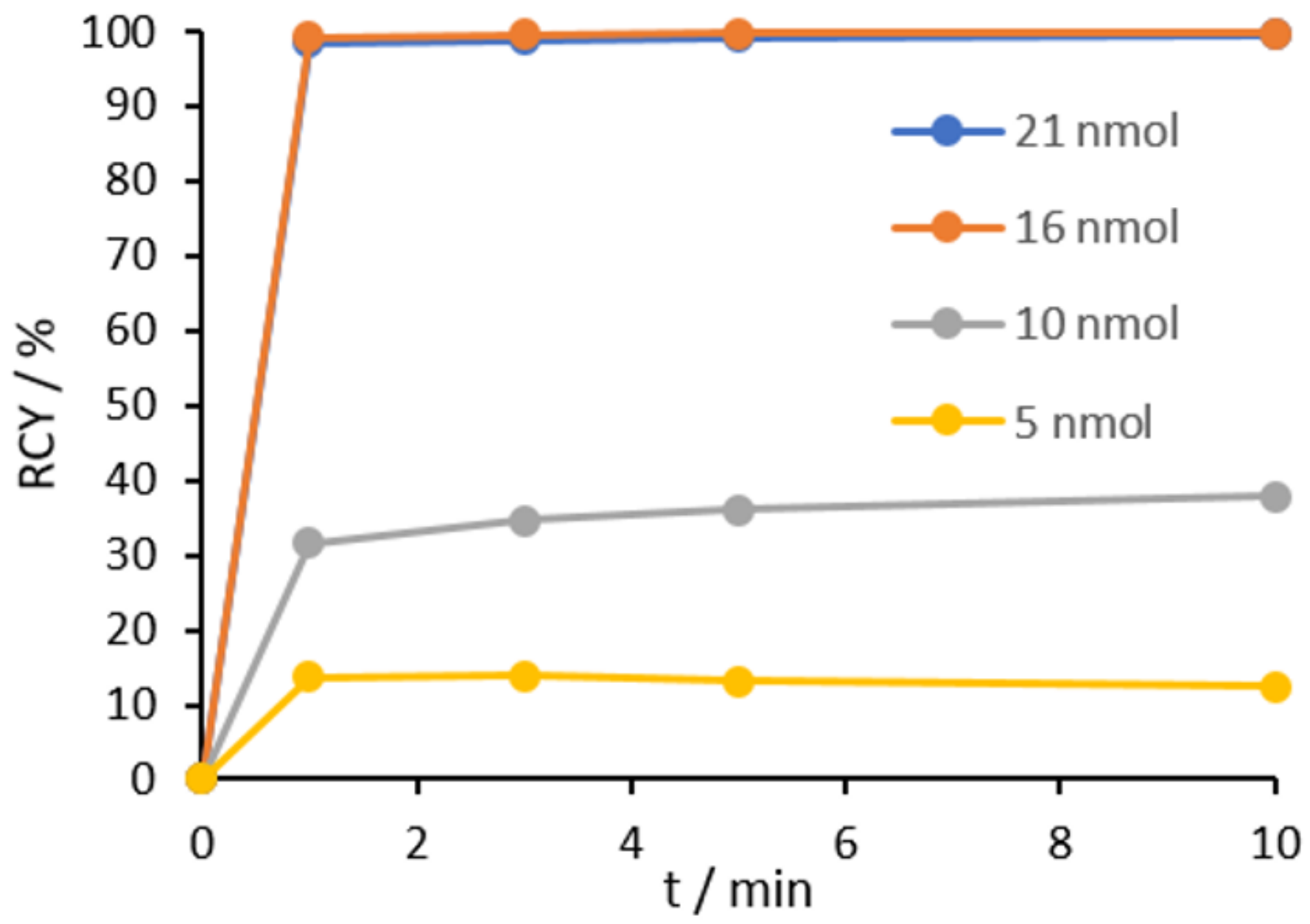

Figure 6

Radiolabeling kinetics of various amounts of [68Ga]Ga-DATA5m.SA.FAPi complex at RT, precursor amounts $>15 \mathrm{nmol}$ result in $\mathrm{RCY}>98 \%$ after $15 \mathrm{~min}$ 


\section{Mouse 1}

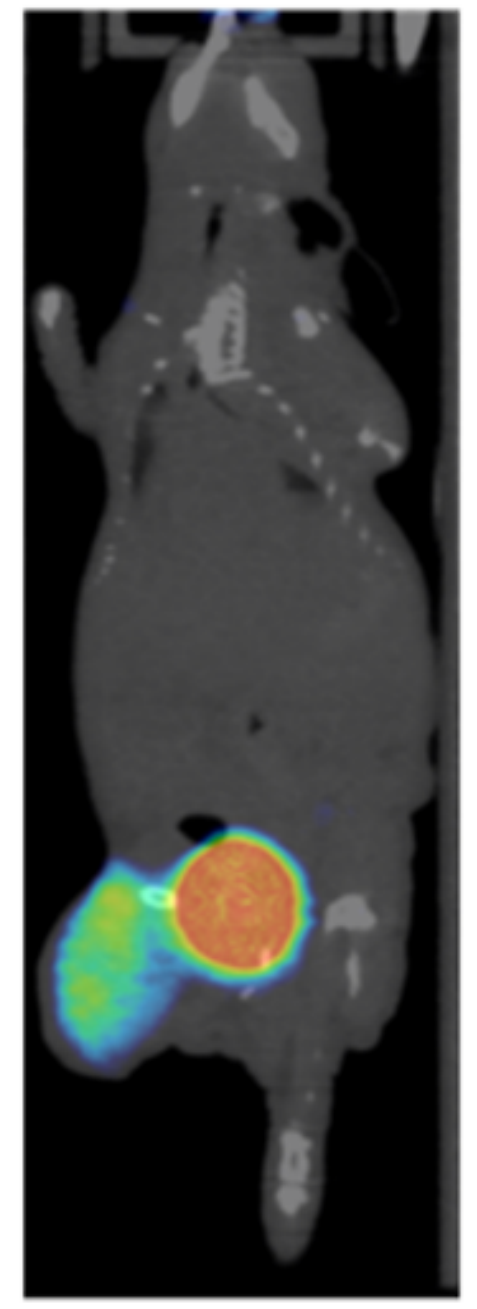

Mouse 2

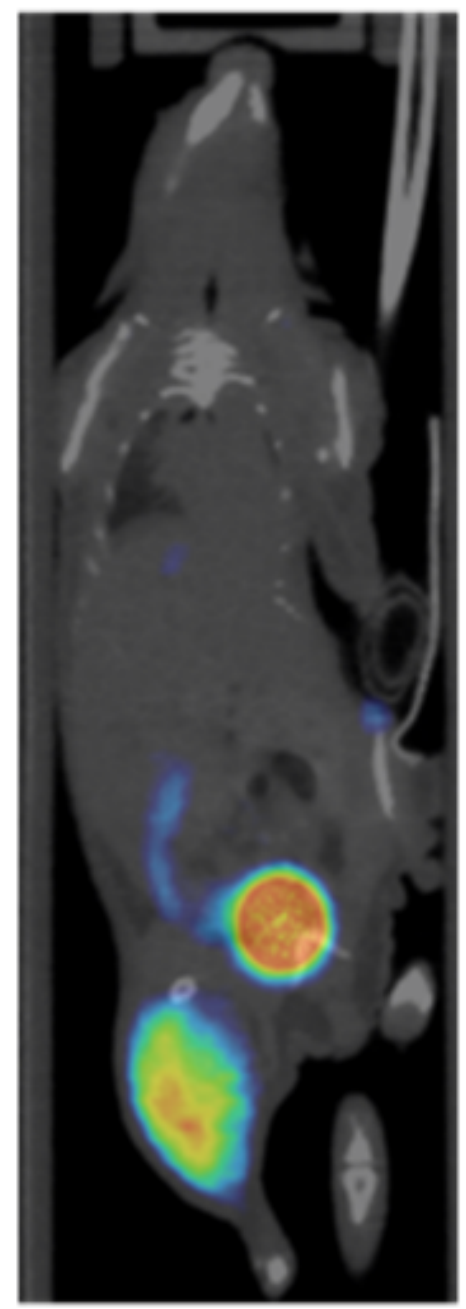

Mouse 3

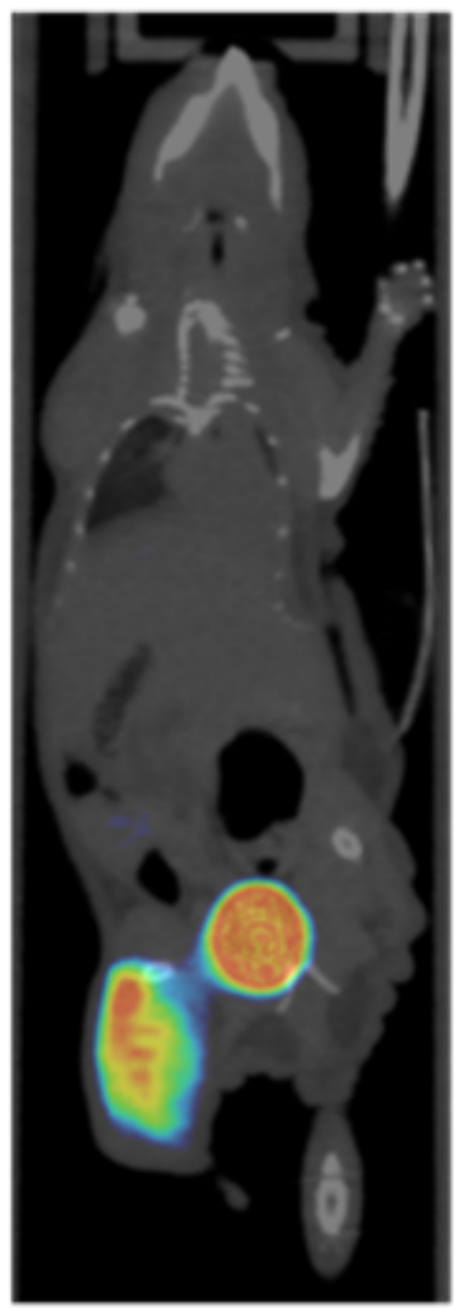

Max

\section{Figure 7}

In vivo evaluation of [68Ga]Ga-DOTA.SA.FAPi uptake in a HT-29 xenograft mouse model. Representative coronal small-animal PET/CT image (MIP) 60 min after injection of [68Ga]Ga-DOTA.SA.FAPi. 

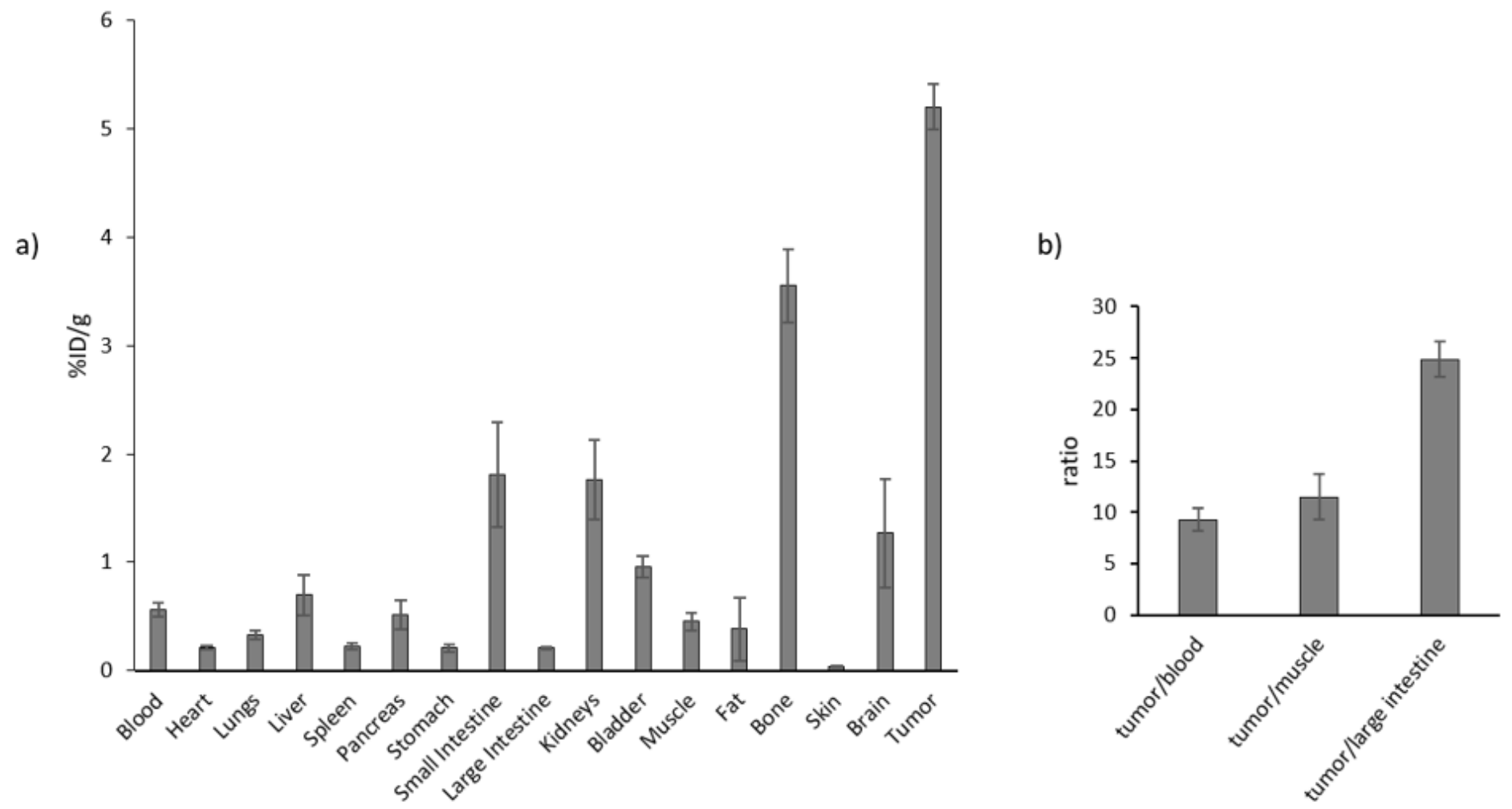

\section{Figure 8}

a) Ex vivo biodistribution of [68Ga]Ga-DOTA.SA.FAPi in HT-29 xenograft mice $(n=3) 1$ h p.i. b) Tumor-toorgan ratios of [68Ga]Ga-DOTA.SA.FAPi in HT-29 xenograft mice $(n=3) 1 \mathrm{~h}$ p.i.

\section{Supplementary Files}

This is a list of supplementary files associated with this preprint. Click to download.

- supportinginformationFAPimanuskript.docx 